\title{
Review \\ The Role of AMPK Signaling in Brown Adipose Tissue Activation
}

\author{
Jamie I. van der Vaart ${ }^{1}$, Mariëtte R. Boon ${ }^{2,3, *}$ and Riekelt H. Houtkooper ${ }^{1, *(D)}$ \\ 1 Laboratory Genetic Metabolic Diseases, Amsterdam Gastroenterology, Endocrinology, and Metabolism, \\ Amsterdam Cardiovascular Sciences, Amsterdam UMC, University of Amsterdam, Meibergdreef 9, \\ 1105 AZ Amsterdam, The Netherlands; jamievandervaart@gmail.com \\ 2 Department of Medicine, Division of Endocrinology, Leiden University Medical Center, \\ 2333 ZA Leiden, The Netherlands \\ 3 Leiden University Medical Center, Einthoven Laboratory for Experimental Vascular \\ Medicine, 2333 ZA Leiden, The Netherlands \\ * Correspondence: M.R.Boon@lumc.nl (M.R.B.); r.h.houtkooper@amsterdamumc.nl (R.H.H.)
}

Citation: van der Vaart, J.I.; Boon, M.R.; Houtkooper, R.H. The Role of AMPK Signaling in Brown Adipose Tissue Activation. Cells 2021, 10, 1122 https://doi.org/10.3390/cells10051122

Academic Editor: Yury Ladilov

Received: 29 March 2021

Accepted: 4 May 2021

Published: 6 May 2021

Publisher's Note: MDPI stays neutral with regard to jurisdictional claims in published maps and institutional affiliations.

Copyright: (c) 2021 by the authors. Licensee MDPI, Basel, Switzerland. This article is an open access article distributed under the terms and conditions of the Creative Commons Attribution (CC BY) license (https:// creativecommons.org/licenses/by/ $4.0 /)$.

\begin{abstract}
Obesity is becoming a pandemic, and its prevalence is still increasing. Considering that obesity increases the risk of developing cardiometabolic diseases, research efforts are focusing on new ways to combat obesity. Brown adipose tissue (BAT) has emerged as a possible target to achieve this for its functional role in energy expenditure by means of increasing thermogenesis. An important metabolic sensor and regulator of whole-body energy balance is AMP-activated protein kinase (AMPK), and its role in energy metabolism is evident. This review highlights the mechanisms of BAT activation and investigates how AMPK can be used as a target for BAT activation. We review compounds and other factors that are able to activate AMPK and further discuss the therapeutic use of AMPK in BAT activation. Extensive research shows that AMPK can be activated by a number of different kinases, such as LKB1, CaMKK, but also small molecules, hormones, and metabolic stresses. AMPK is able to activate BAT by inducing adipogenesis, maintaining mitochondrial homeostasis and inducing browning in white adipose tissue. We conclude that, despite encouraging results, many uncertainties should be clarified before AMPK can be posed as a target for anti-obesity treatment via BAT activation.
\end{abstract}

Keywords: AMPK signaling; brown adipose tissue; energy metabolism; obesity

\section{Introduction}

Obesity is turning into a pandemic and is a growing public health concern worldwide. It has been estimated that around 1.3 billion people were diagnosed with obesity in 2016, and these numbers are still increasing [1]. Despite the lengthy debate about whether obesity can be classified as a disease, a medical consensus regarding this condition has been reached, categorizing obesity as a chronic progressive metabolic disorder by the American Medical Association (AMA) [2-5]. Besides being a metabolic disease itself, obesity also increases the risk of other associated metabolic disorders, such as type 2 diabetes mellitus (T2DM), hypertension, and cardiovascular diseases [4,5]. Treating obesity has proven to be a difficult task due to the multifactorial nature of the disease. Environmental factors (diet, temperature, physical and psychological stress, sleep quality, and physical activity), genetics, and epigenetics all play a role in the onset of obesity, though the main cause is a chronic imbalance between the amount of energy absorbed from food and the energy expended $[5,6]$.

One of the central metabolic organs that play a role in the maintenance of energy homeostasis (the balance between energy intake and energy expenditure) is the adipose tissue, which can roughly be categorized into white adipose tissue (WAT) and brown adipose tissue (BAT) [7]. WAT is primarily noted for being an energy storage depot, 
producing cytokines and an extensive amount of hormones, releasing energy in the form of free fatty acids (FAs), and playing a role in glucose metabolism [8]. In the case of a positive energy balance, this leads to the accumulation of triglycerides in WAT, eventually causing obesity to emerge. In contrast, BAT has a completely different metabolic function. It is a mitochondria-dense tissue that expresses substantial amounts of uncoupling protein 1 (UCP1) and is therefore believed to be a thermoregulatory organ that is able to generate heat to maintain the core body temperature in case of cold exposure (also called adaptive thermogenesis) [9]. In addition, BAT secretes several factors (e.g., fibroblast growth factor 21, interleukin-6) generally called "BATokines" that may impact metabolism as well [10]. It has been long known that BAT is present in rodents, where it plays a crucial role in nonshivering thermogenesis $[11,12]$. BAT was considered to have no physiological relevance in adult humans and was assumed essentially nonexistent. We now know this is not true. Using integrated positron emission tomography and computed tomography (PET-CT) in combination with $\left[{ }^{18} \mathrm{~F}\right]$ fluorodeoxyglucose, several groups independently demonstrated the presence of cold-activated BAT in adult humans mainly in the neck, clavicular, and spine region $[9,11,13]$. The energy-combusting capacity of BAT is mainly mediated through the expression of the tissue-specific UCP1 in its mitochondria. The UCP1 protein enables brown adipocytes to dissipate an electrochemical proton gradient through a proton leak in the inner mitochondrial membrane, leading to the uncoupling of oxidative phosphorylation [14]. This uncoupling makes it possible for mitochondria to break down FAs and other energy substrates to generate energy in the form of heat instead of ATP. New discoveries have led to the characterization of an intermediate type of adipocyte, namely beige, or brite, adipocytes in humans. Brite cells show similarities with both white and brown adipocytes. These brite cells reside in WAT and differentiate from certain precursor cells, or by a transition from white to brite adipocytes, a process called "browning." When unstimulated, these brite fat cells predominantly show WAT-like characteristics, but upon activation, they acquire many mitochondria with high UCP1 expression and high thermogenic capacity $[15,16]$.

Due to its role in energy dissipation rather than energy storage, many efforts have been made to unravel the underlying mechanisms and possible triggers of BAT activation. One major physiological activator of BAT is cold exposure. When a subject is exposed to cold, the hypothalamus will send signals through the sympathetic nervous system (SNS) mediated by norepinephrine that binds the $\beta$-adrenergic receptors ( $\beta 3$ receptor in mice and likely $\beta 2$ receptor in humans) on BAT [17]. This process is subject to several models of physiological regulation, such as the circadian clock [18]. For instance, when the daily rhythm was changed, metabolic processes in skeletal muscle, liver, and BAT were disrupted, leading to an altered glucose and lipid metabolism [19]. More specifically, preclinical studies have shown that prolonged daily light exposure decreases BAT activity through reduced sympathetic outflow to $\beta 3$-adrenergic receptors on BAT and decreased phosphorylation of AMP-activated protein kinase (AMPK) in BAT [20-24]. Altogether, these events lead to reduced FA and glucose uptake by BAT [24].

A second mode of BAT regulation is through intracellular signaling. Among the various signaling pathways that converge on BAT differentiation and activation, AMPK takes a prominent place $[25,26]$. AMPK is a serine/threonine kinase that has been identified as a sensor for intracellular energetic stress $[27,28]$. Moreover, AMPK has broader functions involved in whole-body energy balance via the SNS [21]. Although many studies suggest a link between the AMPK pathway and BAT activation, evidence identifying AMPK as a causal factor for BAT activation is still ambiguous. Especially the mechanisms that regulate activation of BAT via AMPK remain unclear. Therefore, in this review, we will focus on the potential of several AMPK-linked pathways as a target for BAT activation. We will dissect the brain-AMPK-BAT axis into individual components and analyze how these can interact to promote thermogenesis. First, we will discuss the molecular mechanism of AMPK activation, as well as the different compounds that are able to activate AMPK. Secondly, we will explore the potential mechanisms by which AMPK can activate BAT. We 
distinguish three processes that contribute to BAT function, namely, (1) development of BAT, (2) mitochondrial health, and (3) browning. Finally, we will discuss the future of BAT as a potential anti-obesity target.

\section{AMPK Activation through a Wide Variety of Different Compounds}

Previous research has identified the serine/threonine kinase AMPK as an important metabolic switch, with orthologues in different species, that regulates multiple processes involved in lipid metabolism [26,27,29-31]. AMPK consists of three subunits: an $\alpha$-subunit that has catalytic activity, a $\beta$-subunit containing a glycogen-sensing domain, and a $\gamma$ subunit with a regulatory site for binding to AMP (activating) and ATP (inhibitory). Inactivation of AMPK by ATP will lead to inactivation of catabolic processes that generate ATP, whereas activation of AMPK by AMP will lead to inhibition of anabolic processes that consume ATP and activation of catabolic processes [32]. By virtue of this energy-sensing capacity, AMPK can act as a sensor for disturbances in energy balance caused by metabolic stresses at the cellular and whole-body level. Metabolic stressors can be divided into pathological and physiological stresses. Various pathological stresses, such as glucose deprivation, hypoxia, oxidative stress, and ischemia, cause an increase in the AMP:ATP ratio through reduced ATP production. On the other hand, physiological stresses, including exercise and contraction in skeletal muscles, lead to an increase in the AMP:ATP ratio through ATP consumption [33-35]. Upon activation by either of these metabolic stresses, AMP binds the $\alpha$-subunit of AMPK, after which a conformational change is induced that enhances the activity of AMPK and allows the phosphorylation of a threonine residue (Thr-172) by specialized kinases. Additionally, binding of AMP to the $\gamma$-subunit will inhibit dephosphorylation of the Thr-172 thereby prolonging activation of AMPK [22]. This phosphorylation enables AMPK to activate downstream targets, leading to catabolic pathways to be switched on and anabolic pathways to be switched off [36]. As a result, more ATP will be generated or less consumed, contributing to more energy expenditure. Studies over the past two decades have provided critical information on upstream activators of AMPK in vivo, namely, metabolic stress, LKB1, CaMKK2, hormones, and small molecules. We briefly discuss these but also refer the reader to excellent reviews on these topics [28,30,33].

The first mode of regulation involves kinases that activate AMPK through phosphorylation. Assays showing AMPK kinase (AMPKK) activity and Western blot analysis of multiple cellular kinases revealed AMPKK activity of liver kinase B1 (LKB1), suggesting LKB1 to be a major kinase in the upstream AMPK cascade [37]. When mouse embryonic fibroblast cells lacking LKB1 were treated with 5-aminoimidazole-4-carboxamide riboside (AICAR), an AMP-mimic, there was a complete lack of Thr-172 phosphorylation, indicating that there was no AMPK activation. However, the mouse embryonic fibroblast cells did show minor activation of acetyl-CoA carboxylase (ACC), a downstream target of AMPK, suggesting that LKB1 is not the only AMPKK [37].

CaM-dependent protein kinase kinase (CaMKK) was identified as a second protein kinase able to activate AMPK. CaMKK itself is activated through increased levels of intracellular $\mathrm{Ca}^{2+}$. Although CaMKK seems to have weaker interaction with AMPK than LKB1, several studies have revisited the role of CaMKK over the past decade. The CaMKK has two isoforms - CaMKK $\alpha$ and $\mathrm{CaMKK} \beta$. Although the small molecule CaMKK inhibitor STO-609 inhibits AMPK activation in $\mathrm{LKB1}^{-/-}$HeLa cells, it is nonspecific for the isoforms of CaMKK. When CaMKK $\beta$ is experimentally silenced using siRNA, this results in the full reduction of the activation of AMPK. In contrast, silencing of CaMKK $\alpha$ led to no significant effect $[38,39]$, supporting the notion that AMPK can be activated by LKB1 and CaMKK, especially the CaMKK $\beta$ isoform.

A second mode of regulation is through compounds. The mechanism by which these compounds activate AMPK can be divided into three classes, namely, (1) increasing levels of AMP, (2) mimicking one of the in vivo activators, and (3) directly activating AMPK by binding one of the subunits [33]. Although it is beyond the scope of this review to give a detailed description of all of these compounds, we will briefly touch upon a selection of 
interesting compounds (see also, Figure 1 and Table 1). Metformin, a widely prescribed antidiabetic drug, lowers glucose levels in the blood and inhibits Complex I of the respiratory chain, which is a vital enzyme in the electron transport chain. Additionally, metformin can mimic glucose deprivation, which causes transient energy stress in the cell that will contribute to AMPK activation through the first-mentioned mechanism [36,40-42]. Moreover, many mitochondrial poisons and plant-derived drugs, such as oligomycin, resveratrol, and berberine, are able to activate AMPK through respiratory chain inhibition $[33,43,44]$. As for AMP-mimicking drugs, the best described AMP-analogue is AICAR, which can be converted intracellularly into its monophosphate form (called ZMP), consequently mimicking the AMP effects on AMPK $[43,45]$. Finally, the third class can be characterized by a large group of small molecules that can bind to AMPK directly. One example is A769662, a thienopyridine that can allosterically activate AMPK and prevents dephosphorylation of Thr-172 through binding to the Allosteric Drug and Metabolite (ADaM) site, located between the $\beta$-CBM and the N-lobe on the $\alpha$-subunit $[23,46-48]$.

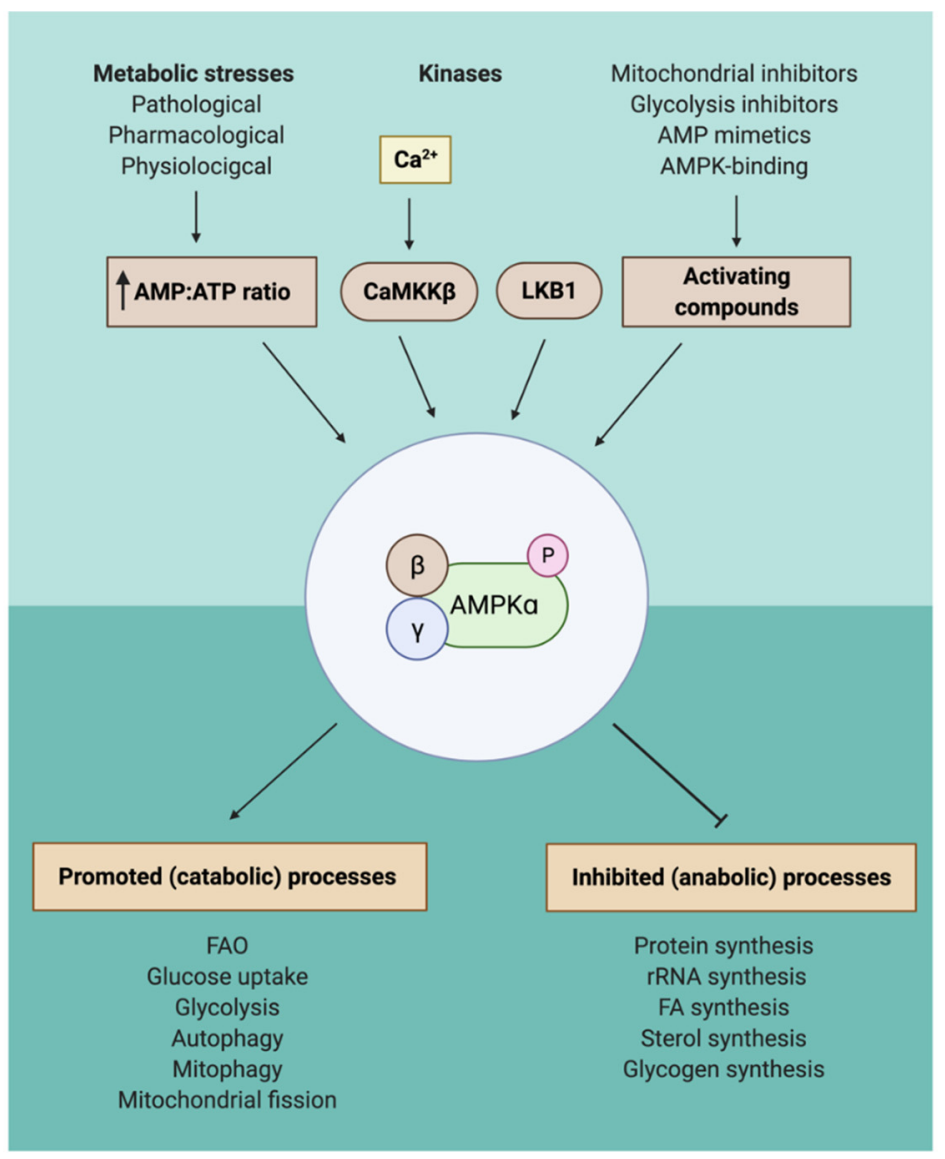

Figure 1. Functional mechanism of upstream regulation of AMPK. Phosphorylation of AMPK can be caused by an increased AMP:ATP ratio, the kinases CaMKK $\beta$ and LKB1, and activating components. Elevated ratios of AMP:ATP are caused by metabolic stresses, which can be divided into pathological, pharmacological, and physiological pathological stresses. CaMKK $\beta$ is activated by increased intracellular $\mathrm{Ca}^{2+}$. Examples of activating compounds are mitochondrial and glycolysis inhibitors, AMP-mimetics, and AMPK-binding compounds. Activation of AMPK will stimulate catabolic processes, leading to ATP production, and inhibit anabolic processes, leading to less ATP consumption. Some examples of the metabolic consequences are shown. Abbreviations: adenosine monophosphate, AMP; adenosine triphosphate, ATP; AMP-activated protein kinase, AMPK; CaMdependent protein kinase kinase beta, CaMKK $\beta$; fatty acids, FA; fatty acid oxidation, FAO; liver kinase B1, LKB1. 


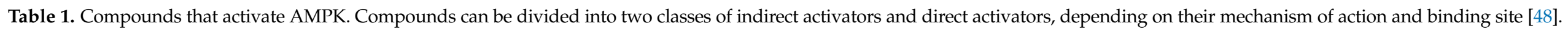

Secondly, AMPK activators can be subclassified into mitochondrial inhibitors, glycolytic inhibitors, AMP mimics, and AMPK-binding compounds.

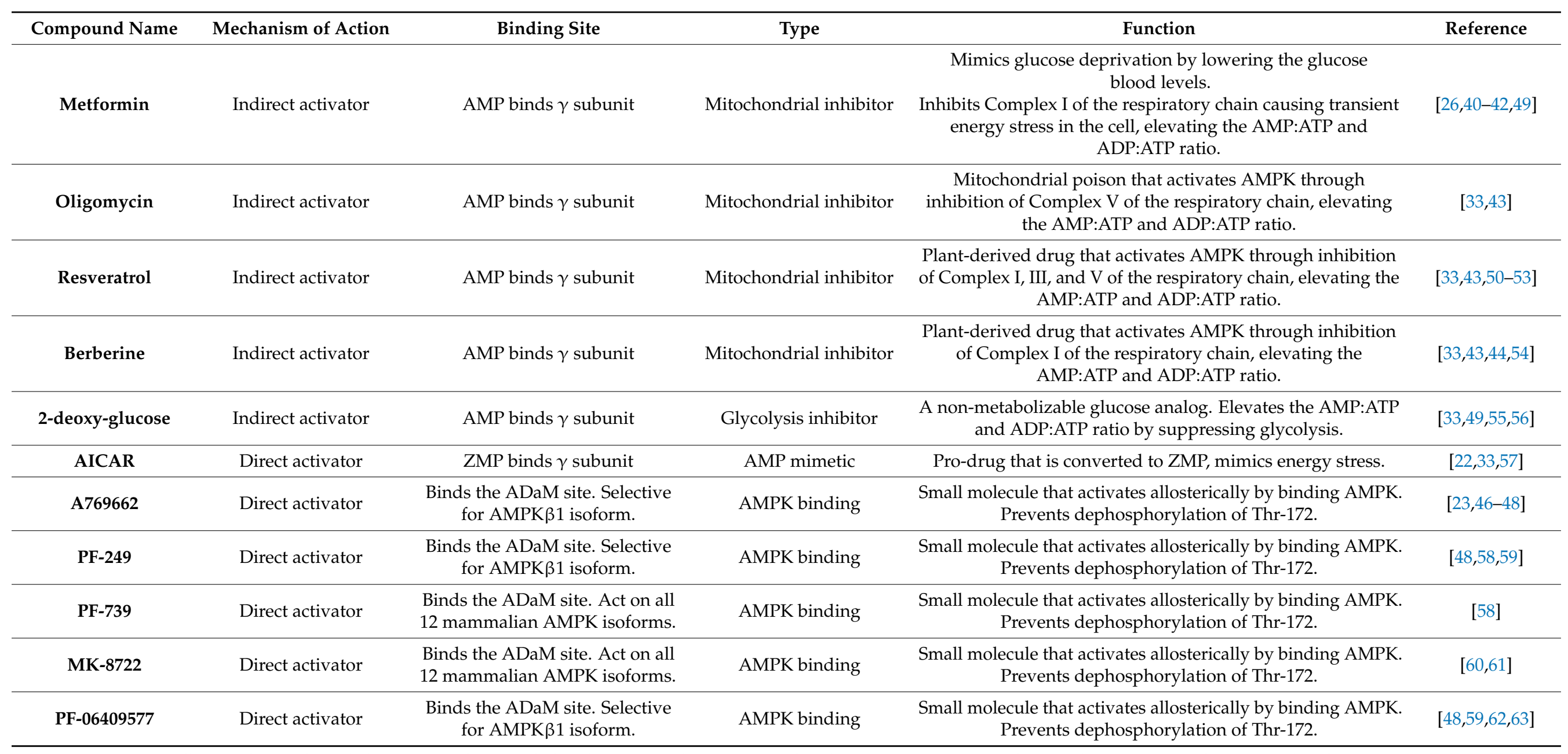

Allosteric drug and metabolite, ADaM; adenosine diphosphate, ADP; adenosine monophosphate, AMP; AMP-activated protein kinase, AMPK; adenosine triphosphate, ATP. 
In conclusion, different kinases and many compounds are able to activate AMPK in different manners $[33,35,37-40,43,46,47,49]$. These regulators can contribute to metabolic health via different signaling cascades, all coming down to activation of AMPK, which will subsequently trigger catabolic processes, including increased FAO, glycolysis, and glucose uptake, processes that are fundamental for BAT activation.

\section{The Functional Mechanism of Regulation of Brown Adipose Tissue by Hypothalamic AMPK}

Cold activates BAT by increasing sympathetic nervous system (SNS) outflow from the hypothalamus toward BAT. Several hypothalamic neurons that are responsible for the regulation of thermogenesis and energy expenditure are located in the arcuate, dorsomedial $(\mathrm{DMH})$, paraventricular, and ventromedial $(\mathrm{VMH})$ nuclei and in the lateral hypothalamus (LHA) and preoptic (POA) area [64,65]. Upon cold exposure, the POA is activated and projects to neurons in the VMH, which will lead to inactivation of AMPK and subsequent sympathetic outflow toward BAT $[64,66,67]$. The link between AMPK (in)activation and BAT involves two separate mechanisms, namely, (1) via downregulation of AMPK in the hypothalamus (Figure 2A) or (2) through activation of AMPK intracellularly in brown adipocytes (Figure 2B). While AMPK activity in brown adipocytes results from a local energy deficit, hypothalamic AMPK is mainly a reflection of whole-body energy balance and increases energy levels through SNS outflow to metabolic organs, such as BAT $[22,26]$. Inhibition of hypothalamic AMPK induces a signaling cascade that consequently causes norepinephrine (NE) to be excreted in the vicinity of brown adipocytes. $\mathrm{NE}$ binds to $\beta 2$-adrenergic (human) or $\beta 3$-adrenergic (rodents) receptors on the surface of brown adipocytes, activating intracellular AMPK, increasing intracellular cAMP, and phosphorylating protein kinase A (PKA), which will induce intracellular lipolysis in BAT. In addition to cold, several compounds and hormones are also suggested to alter BAT thermogenesis through their effect on hypothalamic AMPK activity in the VMH [22]. In this section, we will discuss the function of hypothalamic AMPK and its regulation by different stimuli.

\section{Hormones, Compounds, and Metabolites Regulate AMPK in the Hypothalamus}

The thyroid axis was identified as an important regulator of lipid metabolism and whole-body energy balance [68]. In a condition called hyperthyroidism, excess thyroid hormones are produced characterized by increased energy expenditure and weight loss. In rats, injection of $\mathrm{T} 3$ in the $\mathrm{VMH}$ raises energy expenditure through inactivation of hypothalamic AMPK, stimulation of SNS outflow toward BAT, and activation of thermogenesis $[68,69]$. This effect was reversed by blocking the $\beta 3$-adrenergic receptors, blunting the expression of thermogenic markers in BAT, and preventing reduction in body weight associated with T3 administration [68]. Steroidogenic factor 1 (SF1) neurons in the VMH are responsible for the projection toward the SNS and subsequently BAT in response to T3 treatment since mice lacking SF1 neurons have abnormal VMH development and are obese [26,70,71]. It is thought that SF1 neurons in the VMH play a role in the regulation of energy balance by integrating multiple signals both peripherally and centrally [71-74]. Deletion of AMPK $\alpha 1$ in SF1 neurons leads to a similar effect as observed after T3 injection, including weight loss and increased UCP1 levels in BAT [71]. However, when mice lacking UCP1 were treated with T3, hypothalamic AMPK was not affected, suggesting UCP1 is needed for the T3-mediated effect of thermogenesis [75]. Furthermore, central administration of T3 in rats is associated with increased browning markers of WAT, which was also mediated by hypothalamic AMPK in the VMH $[26,75,76]$. Similar to thyroid hormones, estrogens also play an essential role in energy expenditure. Estradiol levels decrease during menopause in women, leading to decreased energy expenditure and weight gain [77]. When estradiol was administered in hyperphagic rats lacking estradiol, hypothalamic AMPK was inactivated, thermogenic markers in BAT were upregulated and energy expenditure was increased [78]. When the rats were subsequently treated with the AMPK activator AICAR, the anorexic effect evoked by estradiol was diminished. Similar to results found with T3, 
blockage of $\beta 3$-adrenergic reversed the effects of estradiol, increasing body weight and reduced UCP1 expression in BAT [78]. These results suggest that estradiol is indeed able to regulate hypothalamic AMPK, thereby activating BAT thermogenesis. Of note, both thyroid hormone and estradiol are thought to be able to reduce stress in the endoplasmic reticulum, leading to less ceramide synthesis in the $\mathrm{VMH}$, subsequently inhibiting AMPK and promoting BAT activation [71,79].

A

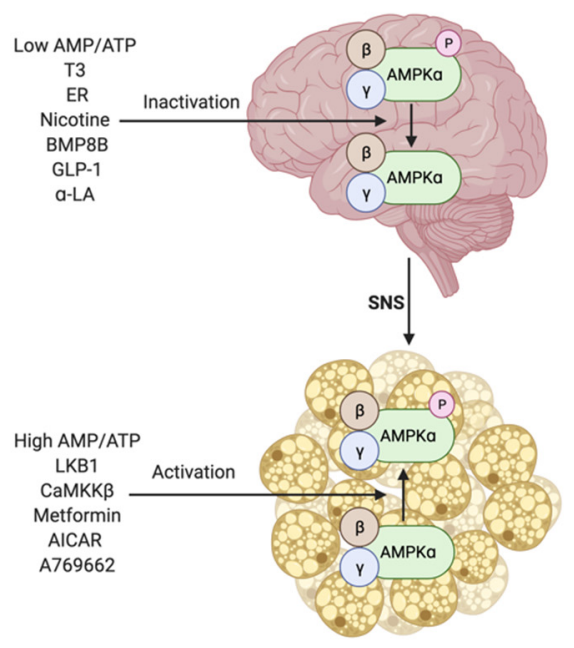

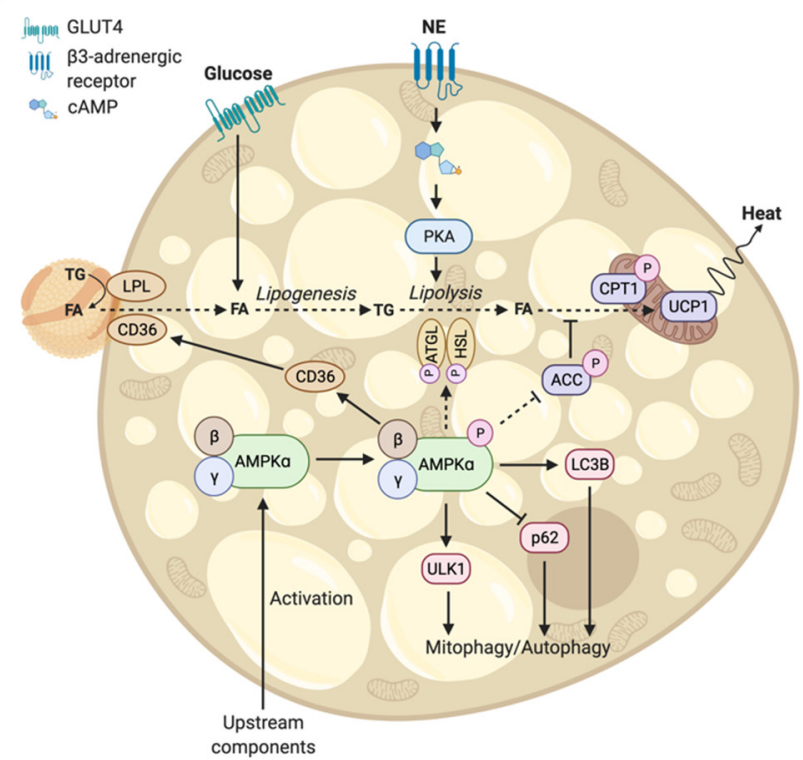

Figure 2. Schematic overview showing the functional mechanism of BAT activation mediated by AMPK. (A) Brain-AMPKBAT axis, where BAT can be activated by inhibition of hypothalamic AMPK, after which the SNS will signal to BAT to upregulate lipolysis, or through direct activation mediated by different upstream components of AMPK. (B) Detailed overview of BAT activation through norepinephrine, excreted by the SNS, or through direct activation of AMPK. Norepinephrine can bind the $\beta 3$-adrenergic receptor, which will subsequently activate cAMP and PKA, ultimately increasing lipolysis and heat production. Upstream components of AMPK, previously described, activate AMPK after which CD36 is translocated to the membrane and LPL is stimulated, resulting in increased uptake of triglyceride-derived FA from lipoproteins and later in lipolysis combined with heat production. In addition, AMPK can release the inhibition of CPT1, increasing FA transport to mitochondria, also contributing to heat production, though this latter part of the signaling cascade is likely to only play a minor role in BAT thermogenesis. The role of AMPK in lipolysis and phosphorylation of ACC has not been proven experimentally; therefore, dashed lines are used in this figure. Abbreviations: acetyl-CoA carboxylase, ACC; 5-Aminoimidazole-4-carboxamide ribonucleotide, AICAR; alpha-lipoic acid, $\alpha$-LA; adenosine monophosphate, AMP; AMP-activated protein kinase, AMPK; adipose triglyceride lipase, ATGL; adenosine triphosphate, ATP; bone morphogenetic protein 8B, BMP8B; cyclic AMP, cAMP; CaM-dependent protein kinase kinase beta, CaMKK $\beta$; cluster of differentiation 36, CD36; carnitine palmitoyltransferase 1, CPT1; estrogen receptor, ER; fatty acid, FA; glucagon-like protein 1, GLP1; hormone-sensitive lipase, HSL; low-density lipoprotein, LDL; liver kinase B1, LKB1; protein kinase A, PKA; sympathetic nervous system, SNS; triglycerides, TG; triiodothyronine, T3; uncoupling protein 1, UCP1.

Nicotine, an important constituent of cigarette smoke, also influences energy expenditure, mediated by inhibition of hypothalamic AMPK in the VMH and subsequent sympathetic outflow to BAT $[80,81]$. Research has also pointed out that peripheral nicotine treatment in rats led to increased expression of UCP1 in BAT [82,83]. This may at least partly explain why nicotine withdrawal after cessation of smoking is associated with reduced energy expenditure. 
Multiple studies have identified that several bone morphogenetic proteins (BMPs), part of the growth factor $\beta$ superfamily, are key actors in thermogenesis. BMPs have pleotropic effects in different tissues. In adipose tissue, BMP2, BMP4, BMP7, and BMP8B are associated with the differentiation of preadipocytes to brown adipocytes [84-88]. BMP8B is expressed in BAT and the hypothalamus and is associated with increased thermogenesis $[66,89]$. Mice lacking BMP8B have impaired thermogenesis, while BMP8B treatment led to an elevated response to adrenergic stimulation with norepinephrine [89]. Stereotaxic administration of BMP8B specifically in the VMH in rats also decreased hypothalamic AMPK, increased thermogenic markers in BAT, and increased browning markers in WAT [90]. This effect was not found when BMP8B was administered in the LHA, suggesting the effects are specific for the $\mathrm{VMH}$. To support further the hypothesis that BMP8B only has an effect on AMPK in the VMH and not the LHA, AMPK $\alpha$ was overexpressed in the VMH with a constitutive promotor, which completely abolished the BMP8B effect on thermogenesis [89]. In contrast, when a dominant-negative form of $\mathrm{AMPK} \alpha$ was expressed in the $\mathrm{VMH}$, there was a greater thermogenic effect after central administration of BMP8B. Combined, these data suggest that BMP8B is able to increase thermogenesis in an AMPK-mediated manner in the $\mathrm{VMH}$.

Glucagon-like peptide-1 receptor (GLP-1R) agonists are widely used in clinical practice as therapy for type 2 diabetes and obesity and one of its beneficial effects is that it induces a negative energy balance by decreasing appetite. However, we recently showed that treatment of healthy lean men with the GLP-1R agonist exenatide enhanced [ $\left.{ }^{18} \mathrm{~F}\right]$ FDG uptake by BAT as measured by PET-CT scan, pointing to increased BAT activity [91]. In rats, injection of GLP-1 in the DMH increases core body temperature and expression of thermogenic markers [92]. Central administration of the GLP-1R agonist exendin-4 increases sympathetic outflow toward BAT, leading to increased UCP1 protein levels, reduced lipid content, and increased FA uptake [93]. However, it is not clear if the effects of GLP-1 and exendin- 4 on BAT thermogenesis are mediated by AMPK signaling. Nevertheless, the GLP-1R agonist liraglutide is able to inhibit hypothalamic AMPK in the VMH [94,95]. In rats, central administration of liraglutide induced weight loss, significantly increased the temperature of BAT, gene expression of thermogenic markers in BAT, browning markers in WAT, and protein levels of UCP1 in both WAT and BAT [95]. In line with the effects observed after BMP8B administration, constitutive expression of AMPK $\alpha$ or AICAR treatment in the VMH of rats attenuated the liraglutide-induced UCP1 expression in BAT, suggesting that the effect of liraglutide on weight loss and UCP1 expression is indeed mediated by AMPK in the VMH [22,95].

Lastly, it was found that metabolites also influence hypothalamic AMPK [67]. For example, $\alpha$-lipoic acid ( $\alpha$-LA), a short-chain FA that is a cofactor of several enzymes, reduced body weight in rats by increasing energy expenditure and gene expression of Ucp1 in BAT and WAT [96]. Furthermore, administration of $\alpha$-LA inhibited hypothalamic AMPK and this effect was diminished after activation of AMPK with AICAR or after overexpression of AMPK $\alpha$ in the brain. In obese subjects, 8-week administration of $\alpha$-LA resulted in a moderate reduction of body weight $[97,98]$. Nevertheless, these results did not elucidate the mechanism behind the weight loss; thus, it is not clear if this is due to increased energy expenditure, and whether AMPK was involved.

In summary, there is a large group of different compounds, ranging from hormones and growth factors to small molecules and metabolites that regulate hypothalamic AMPK ref. $[22,26,33,44,57,68,69,99]$. As a general concept, these compounds downregulate hypothalamic AMPK in the VMH and activate BAT-mediated thermogenesis. In the next section, we will discuss the role of AMPK in the activation of brown adipocytes in more detail.

\section{The Functional Mechanism of AMPK-Mediated Activation in Brown Adipocytes}

In contrast to the role of AMPK in the hypothalamus preventing a negative energy balance by reducing the sympathetic outflow, AMPK plays a very different role in BAT. In BAT, AMPK is directly activated by (1) cold exposure that stimulates $\beta$-adrenergic 
signaling, (2) kinases, (3) compounds, as described in Section 1 and Figure 2, and (4) by downregulation of hypothalamic AMPK [100]. Intracellularly, in brown adipocytes, AMPK can phosphorylate adipose triglyceride lipase (ATGL) and hormone-sensitive lipase (HSL), enzymes that promote intracellular lipolysis, again via PKA. This generates free FAs that can bind to UCP1, thereby causing a conformation change that activates the protein, which leads to dissipation of the electrochemical gradient across the mitochondrial inner membrane and will promote heat production in mitochondria, though studies have shown that AMPK may only have a minimal role in adipocyte lipolysis [100]. Additionally, AMPK can promote translocation of the cluster of differentiation 36 (CD36) and activation of lipoprotein lipase (LPL) that play an important role in extracellular lipolysis and subsequent uptake of triglyceride (TG)-derived fatty acids from circulating lipoproteins. Lastly, AMPK can phosphorylate $\mathrm{ACC}$, thereby releasing the inhibition of carnitine palmitoyltransferase 1 (CPT1) at the mitochondria (Figure 1). The CPT1 protein is responsible for FA transport into mitochondria, providing fuel for oxidative phosphorylation and dissipation of heat by UCP1. This role is particularly clear in the liver. However, in mice with an ACC knockin mutation, AMPK phosphorylation and removal of CPT1 inhibition did not influence BAT thermogenesis [100]. It is hypothesized that AMPK is required for the acute activation of BAT thermogenesis, but the effect of AMPK on ACC may have a more inferior role in BAT thermogenesis as previously thought.

Studies with adipocyte-selective deletion of the $\alpha$-subunit or the $\beta$-subunit have shown that AMPK is essential in multiple processes in BAT, including mitochondrial structure and function, energy expenditure, and brown adipocyte development $[23,100,101]$. In this section, we will discuss activation and regulation of BAT via the AMPK axis by means of three important processes: (1) development of BAT, (2) mitochondrial health, and (3) browning (Figure 3).

\subsection{Development of Brown Adipocytes}

The existing body of research on the relation between BAT and AMPK suggests an important role for AMPK in the development of brown adipose tissue. To further elucidate the pathways involved in brown adipogenesis, chemical inhibitors, and siRNA technologies were used to block different AMPK-linked signaling cascades, such as MAPKs, the LKB1AMPK pathway, the mTOR pathway, and Wnt signaling cascades and effects on brown adipogenesis were studied [102]. Two important upstream and downstream proteins of the AMPK pathways are LKB1 and tuberous sclerosis complex 2 (TSC2), respectively. LKB1 activates AMPK when nutrients are low, which in turn causes phosphorylation of TSC2, giving the cell a stress signal that will lead to inhibition of mTOR, independent of protein kinase B (PKB), also known as Akt [103]. In contrast, mTOR is activated in an Akt-dependent mechanism that negatively regulates TSC2, leading to cell growth and proliferation [104]. Furthermore, AMPK directly regulates mTOR via the phosphorylation of the regulatory-associated protein of mTOR (RAPTOR), which is a binding partner of mTOR, leading to inhibition of mTOR $[103,105]$. Altogether, these findings suggest a link between AMPK and mTOR, and the next question is whether the AMPK-mTOR cascade is also involved in the development of brown adipocytes. Research suggests that the mTOR pathway is vital for the early stages of brown adipocyte differentiation from preadipocytes to brown adipocytes. In contrast, in the later stages of BAT development, activation of AMPK leads to phosphorylation of TSC2 and RAPTOR, and consequent inhibition of mTOR-mediated proliferation of brown adipocytes $[33,102]$. Therefore, the AMPK-mTOR axis plays an important role in the time-resolved regulation of brown adipogenesis $[33,106]$. Multiple studies have shown that mTOR is able to enhance glucose uptake by increased translocation of the GLUT1 transporter in BAT $[107,108]$. This suggests that sustained inhibition of mTOR through AMPK is not a viable strategy for BAT activation because inhibition might have a negative effect on glucose uptake. 


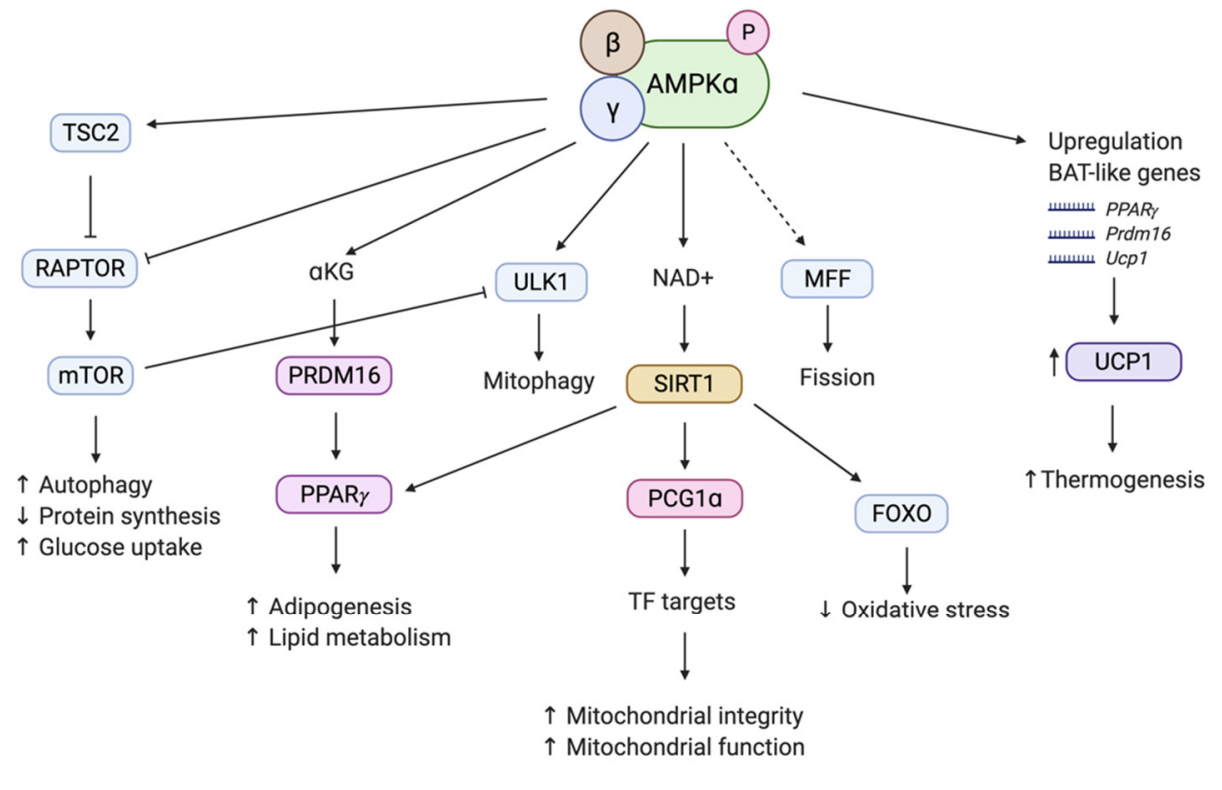

Development of brown adipocytes

Mitochondrial health

Browning

Figure 3. Selection of AMPK-mediated signaling cascades involved BAT activation. The pathways are divided into three processes, namely, the development of brown adipocytes, mitochondrial health, and browning. The signaling cascades depicted here are simplified and are far more complex and interconnected than shown. Firstly, mTOR is a major kinase involved in autophagy and protein syntheses in the developmental stage and glucose uptake in adult brown adipocytes. Secondly, PRDM16 is an essential DNA-binding transcription factor, which can indirectly induce adipogenesis and lipolysis. Thirdly, SIRT1 is an important kinase involved in mitochondrial health and also connects development and mitochondrial homeostasis by influencing the transcription factor PPAR $\gamma$. Finally, an abundance of the UCP1 protein is associated with increased thermogenic capacity and is indirectly regulated by AMPK. The role of AMPK in the phosphorylation of MFF has not been proven experimentally; therefore, a dashed line is used in this figure. Abbreviations: AMP-activated protein kinase, AMPK; $\alpha$-ketoglutaric acid, $\alpha$ KG; forkhead box protein O, FOXO; mitochondrial fission factor, MFF; nicotinamide-adeninedinucleotide, NAD; peroxisome proliferator-activated receptor- $\gamma$ co-activator 1 , PGC1 $\alpha$; peroxisome proliferator-activator receptor, PPAR $\gamma$; PR domain containing 16 protein, PRDM16; regulatory-associated protein of mTOR, RAPTOR; sirtuin-1, SIRT1; transcription factor, TF; tuberous sclerosis complex 2, TSC2; uncoupling protein 1, UCP1; Unc-51 like autophagy activating kinase, ULK1.

Epigenetic markers are of great importance in the development of cells from progenitor cells. Methylation and acetylation of key developmental genes are critical processes in the development of all cell types. For brown adipogenesis, a key transcriptional regulator is the PR domain containing 16 protein (PRDM16) [109]. This regulator is able to bind and activate the peroxisome proliferator-activator receptor (PPAR $\gamma$ ), an essential DNA-binding transcriptional factor, thereby stimulating adipogenesis and increasing lipolysis. Loss of PRDM16 causes differentiation of brown adipocytes toward skeletal myoblasts, whereas expression of PRDM16 induces differentiation into BAT, additionally suggesting a different cell lineage for BAT and WAT [44]. Further investigation into the regulation of adipogenesis by PRDM16 revealed a key role for AMPK in activation of PRDM16 through $\alpha$-ketoglutarate ( $\alpha \mathrm{KG}$ ) [110]. Since isocitrate dehydrogenase 2 (IDH2) is responsible for the conversion of isocitrate to $\alpha \mathrm{KG}$ in mitochondria and $\alpha \mathrm{KG}$ levels are regulated by AMPK, it was investigated whether AMPK regulates IDH2, thereby aiding adipogenesis [111]. It was found that depletion of AMPK $\alpha 1$ reduced intracellular IDH2 activity, leading to less $\alpha \mathrm{KG}$, which is needed for demethylation of the Prdm16 promotor $[110,111]$. Furthermore, deletion of the same AMPK $\alpha 1$ subunit resulted in weakened expression of Prdm16 in BAT progenitor cells, which led to reduced adipogenesis and fewer multilocular lipid droplets [101]. These results suggest that AMPK is needed for 
PRDM16 expression by reducing IDH2 expression and indirectly decreasing $\alpha$ KG levels and subsequent demethylation of the $\operatorname{Prdm} 16$ promotor.

\subsection{Mitochondrial Health}

A major part of the thermogenic capacity of BAT is dependent on its mitochondrial abundance. A growing body of research shows an essential role for AMPK in the maintenance of mitochondrial homeostasis [112]. More specifically, in addition to serving a role as an energy sensor, AMPK can also activate transcriptional regulators of mitochondrial biogenesis, mitochondrial fission, and mitophagy $[15,110]$. It is beyond the scope of this review to give a detailed description of the signaling pathways that underlie the intrinsic regulation of all these processes, but we refer to comprehensive reviews on the relation between AMPK and mitochondrial health for more detail $[112,113]$.

AMPK-activating compounds such as metformin, resveratrol, berberine, and AICAR all have an effect on mitochondrial health in brown adipocytes $[33,43,45]$. For example, metformin activates AMPK, which in turn inactivates ACC, thereby releasing the inhibition on CPT1 and increasing lipolysis and FAO [22,40,114]. Moreover, metformin is able to phosphorylate HSL at PKA phosphorylation sites, also contributing to lipid breakdown. Resveratrol can activate AMPK, which will subsequently lead to activation of sirtuin-1 (SIRT1) through deacetylation, activation of the peroxisome proliferator-activated receptor- $\gamma$ co-activator 1 (PGC1 $\alpha$ ) and to increased mtDNA content, mitochondrial size and abundance, eventually leading to reduced lipogenesis and enhanced FAO [15]. Mice that were treated with resveratrol showed increased expression of both UCP1, SIRT1, and PGC1 $\alpha$ in BAT and increased BAT mitochondrial function, all contributing to higher energy expenditure [50,51]. Furthermore, resveratrol prevented high-fat-diet-induced obesity and insulin resistance in mice [51]. Additionally, AMPK-mediated activation of SIRT1 will also lead to activation of PGC1 $\alpha$ and PPAR $\gamma$ [15], linking mitochondrial biogenesis to developmental processes in brown adipocytes and lipolysis. Likewise, berberine is able to increase UCP1 and PGC1 $\alpha$ expression through an AMPK-mediated pathway. Despite not being fully elucidated, multiple studies suggest that berberine activates AMPK by increasing the AMP:ATP ratio and by inhibiting the mitochondrial complex I of the respiratory chain $[44,99]$. In parallel to these effects on mitochondria, it was also shown that PRDM16 was indispensable for berberine-induced brown adipogenesis [44]. This suggests that berberine has the potential to activate AMPK-mediated thermogenesis in BAT via two mechanisms, namely, by regulating the expression of key proteins in mitochondrial biogenesis (UCP1 and PGC1 $\alpha$ ) and by regulating an important epigenetic factor of brown adipogenesis (PRDM16) [44,99]. Although not thoroughly investigated in BAT, AICAR-mediated activation of AMPK has been shown to lead to increased glucose uptake, FA uptake, and insulin sensitivity in skeletal muscle in mice [115]. Since skeletal muscles and BAT are connected through common progenitors and because muscles are able to cause metabolic stress signals through contraction thereby activating AMPK, one could speculate that AICAR might have similar effects on BAT. These findings emphasize that most genes involved in mitochondrial biogenesis are under the regulation of PGC1 $\alpha$ and PPAR $\gamma$ [112]. When taking a genetic approach, mice lacking the $\beta$-subunit of AMPK showed disrupted cristae and reduced mitochondrial respiration, suggesting defective mitochondrial structure and function [100].

The process of mitochondrial fission is vital for the maintenance of a healthy mitochondrial population. Indeed, mitochondrial fission can increase the mitochondrial surface, thereby enhancing the ability of free FAs to bind to and activate UCP1 [116]. Once activated, AMPK is able to induce fragmentation of mitochondria across cell types with morphometrically distinct mitochondrial networks [117]. Mitochondrial fission is mainly regulated through mitochondrial fission factor (MFF), which is a receptor of dynamin-like protein 1 (DRP1) on the mitochondrial outer membrane, an essential protein for mitochondrial fission. Proteomics screens revealed two phosphorylation sites on MFF that are substrates for AMPK. Additionally, activation of AMPK increases the localization of DRP1 
in mitochondria [117], thus linking AMPK and mitochondrial fission via phosphorylation of MFF and subsequent activation of DRP1 $[108,109]$. Lastly, to maintain a healthy network of mitochondria, biogenesis is critical, but it is also essential for old mitochondria to be broken down. Selective autophagy of mitochondria, or mitophagy, is regulated by AMPKmediated phosphorylation of Unc-51 such as autophagy activating kinase (ULK1) [112]. Inhibition of mTOR by AMPK also relieves the inhibition of ULK1 by mTOR, revealing the great intricacy by which these processes are regulated. However, when looking at the same mouse model mentioned earlier, lacking the $\beta$-subunit, the protein levels of PGC1 $\alpha$ and phosphorylation levels of MFF were not different from the control mice, suggesting no alteration in mitochondrial number [100]. In contrast, the ULK1 protein show reduced phosphorylation in the AMPK $\beta$ knockout mice, compared to the control, leading to less mitochondrial clearance.

Taken together, AMPK is of vital importance in maintaining BAT by regulation of mitochondrial health. Its contribution in cold-induced thermogenesis in BAT involves regulation of mitochondrial structure, function, and mitophagy but is not essential for mitochondrial fission.

\subsection{Browning}

Brite cells and their role in thermogenesis are only now beginning to be unraveled. Although very similar in function, BAT and brite cells develop in a distinct manner with different signaling cascades [102,106,118]. AMPK is a key regulator in the formation of brite cells located in WAT (browning) [119], as shown through a high-throughput screen combined with small hairpin RNA (shRNA) knockdown [118]. This confirms earlier results when AMPK was silenced by siRNAs in brown adipocytes, showing that brown adipogenesis was completely arrested [102]. AMPK inhibition led to reduced proliferation of brown preadipocytes to mature brown adipocytes [106]. Specific knockdown of the $\alpha 1$ subunit of AMPK led to altered proliferation, favoring fibrogenesis instead of brown adipogenesis, supporting a similar lineage between skeletal muscles and BAT [23,101,106,118]. Moreover, independent knockdown of the AMPK subunits AMPK $\alpha 1$, AMPK $\alpha 2$ and combined knockdown of the subunits AMPK $\beta 1$, AMPK $\beta 2$, AMPK $\gamma 1$, and AMPK $\gamma 3$, led to decreased abundance of UCP1 in white adipose tissue, suggesting reduced browning $[110,118]$. When mice were treated with the $\beta$-adrenergic agonist CL316,243, the mRNA expression of important markers for browning, such as Cidea, Ppara, Pdk4, and Ucp1, were all upregulated in the control mice but not in the AMPK $\beta 1 /$ AMPK $\beta 2$ knockout mice [100]. These data suggest that AMPK is essential for $\beta$-adrenergic-mediated browning. AMPK activating compounds also induce browning of WAT toward brite cells $[46,47,102]$. For instance, when mice were treated with AICAR, they showed increased UCP1 protein abundance in WAT that correlated with the number of brown-like adipocytes [102]. Together, these data suggest an important role for AMPK in WAT browning resulting in the physiological regulation of thermogenesis, although the elucidation of the full mechanism requires additional investigation.

Concluding, AMPK can regulate adipogenesis through a variety of partly intersecting processes including inhibition of the mTOR pathway, demethylation of PRDM16, and activation of PPAR $\gamma$. AMPK has an important role in mitochondrial homeostasis through signaling cascades involving PGC1 $\alpha$, PPAR $\gamma$, MFF, and ULK1. Finally, AMPK activation is a major inducer of the browning process of brite cells. Altogether, there is compelling evidence that AMPK is involved in a multitude of developmental and functional processes of BAT and that it can activate BAT via many different signaling pathways.

\section{Discussion}

The discovery of functional BAT has led to a growing interest in BAT as a therapeutic target for obesity because activation of BAT contributes to energy metabolism, which may result in creating a negative energy balance. The purpose of the current review was to determine whether AMPK could be used as a target for BAT activation. Although 
there is compelling evidence that AMPK can activate BAT, many facets of the precise mechanism are still unknown, and studies were mainly performed in mouse models. For instance, rather than the classical BAT cells, there may be a prominent role for brite adipocytes upon AMPK activation [110,118]. In addition, BAT volume diminishes with age and obesity, providing another reason to turn to alternative tissues, such as brite cells, to increase energy expenditure. In line with this, the question of whether BAT is a plausible target for the treatment of obesity in humans has been a frequently investigated matter. Unfortunately, AMPK-activating compounds that were mentioned in this review were mostly investigated in cultured cells, mice, or rats, with the exception of resveratrol, berberine, and metformin. This makes it particularly challenging to apply the results as an integrated treatment for obesity, also due to the complexity of this disease, which is hard to mimic with animal models or cell cultures. Nevertheless, there are a few clinical trials published in which BAT activators were tested for their ability to activate BAT in humans. Though most of these studies are short term and therefore cannot draw definite conclusions on their possible therapeutic use as anti-obesity treatment. They do, however, give more insight into the induction of BAT via AMPK and the potential positive effect on humans with obesity. A recent early phase 1 clinical trial tested the effect of mirabegron, a $\beta 3$-adrenergic receptor agonist, on older human subjects with obesity and insulin resistance, showing that mirabegron substantially improved glucose metabolism and induced browning of WAT (NTC02919176) [120]. Similar results were found in the phase 1 clinical trial with healthy young women (NTC03049462) [121]. Although these findings were not directly linked to activation of BAT via AMPK, the results underline the significance of BAT as a therapeutic target for obesity. Interestingly, besides AMPK, other compounds are also able to increase energy expenditure and lipid homeostasis [122]. Recent research into the hormone FGF21 has indicated that it is able to activate AMPK in adipocytes $[122,123]$. However, this does not explain the beneficial effects since FGF21 treatment is not dependent on AMPK or ACC, suggesting that FGF21 and AMPK work synergistically [124]. Therefore, combinatorial treatment with FGF21 and AMPK activators may have enhanced therapeutic efficacy as an anti-obesity treatment because of these divergent signaling routes. Finally, additional research investigating brite cells identified UCP1-independent thermogenic pathways regulated by creatine and $\mathrm{Ca}^{2+}$ cycling. These compounds can stimulate nonshivering thermogenesis in brite cells, independently of UCP1, through stimulation of the tricarboxylic acid cycle, electron transport chain, and FA reesterification pathways [125-127]. There is abundant room for further progress in determining the importance of AMPK in these and other pathways.

Another factor that complicates the study of in vivo effects of AMPK activation in BAT or browning is the fact that the most used method to activate BAT, namely, cold, also affects other tissues such as skeletal muscle and the liver, and more studies should focus on this intertissue relationship. For example, a study quantifying BAT activation and whole-body glucose metabolism in patients with T2DM after 10 days of cold acclimation showed only a small increase in $\left[{ }^{18} \mathrm{~F}\right] \mathrm{FDG}$ uptake by BAT despite a marked improvement in glucose metabolism [128]. In a follow-up study, the experiment was repeated, but shivering was prevented, leading to a complete reduction of the favorable effects [129]. This suggests that either muscle contraction (shivering) or a strong cold stimulus is needed to stimulate the positive effects of BAT. The question remains whether the physiological changes can be ascribed to activation of BAT, which is estimated to expend between 25 and $211 \mathrm{kcal} / \mathrm{d}$ [130]. It is possible that BAT releases endocrine factors that regulate skeletal muscles [131,132], which would mean that the effect on the muscle is indirect and still requires BAT activation. However, it should be noted that most of the human BAT studies were performed using ${ }^{18} \mathrm{FDG}-\mathrm{PET}-\mathrm{CT}$ scans to measure glucose uptake as a proxy of BAT activation. This is far from an ideal visualization modality in subjects with type 2 diabetes that are severely insulin resistant, which very likely results in less ${ }^{18} \mathrm{FDG}$ uptake by metabolic tissues including BAT. Therefore, a tracer based on triglyceride-derived fatty 
acid uptake is likely superior. Altogether, the debate about the relevance of BAT for energy expenditure and obesity treatment is all but resolved.

In conclusion, AMPK integrates a wide range of inputs and activates various downstream pathways. There is plenty of evidence connecting AMPK and BAT activation through different signaling cascades. To minimize the side effects when therapeutically targeting AMPK, further research should focus on identifying key effectors of thermogenesis. Many questions remain to be answered before the development of an anti-obesity treatment via AMPK-mediated BAT activation in humans.

Funding: Work in the Houtkooper group is financially supported by a VIDI grant from ZonMw, the Netherlands (no. 91715305), and the Velux Stiftung, Switzerland (no. 1063). MRB is supported by a VENI grant from ZonMw, the Netherlands (no. 09150161910073).

Acknowledgments: The figures were created using the online tool BioRender.com (accessed on 30 April 2021).

Conflicts of Interest: The authors declare no conflict of interest.

\section{References}

1. Oussaada, S.M.; van Galen, K.A.; Cooiman, M.I.; Kleinendorst, L.; Hazebroek, E.J.; van Haelst, M.M.; Ter Horst, K.W.; Serlie, M.J. The Pathogenesis of Obesity. Metabolism 2019, 92, 26-36. [CrossRef] [PubMed]

2. Heshka, S.; Allison, D.B. Is obesity a disease? Int. J. Obes. Relat. Metab. Disord. 2001, 25, 1401-1404. [CrossRef] [PubMed]

3. Downey, M. Results of expert meetings: Obesity and cardiovascular disease. obesity as a disease entity. Am. Heart. J. 2001, 142, 1091-1094. [CrossRef]

4. Via, M.A.; Mechanick, J.I. Obesity as a disease. Curr. Obes. Rep. 2014, 3, 291-297. [CrossRef] [PubMed]

5. Bray, G.A.; Kim, K.K.; Wilding, J.P.H. Obesity: A chronic relapsing progressive disease process. A position statement of the world obesity federation. Obes. Rev. 2017, 18, 715-723. [CrossRef]

6. $\quad$ Pillon, N.J.; Loos, R.J.F.; Marshall, S.M.; Zierath, J.R. Metabolic consequences of obesity and type 2 diabetes: Balancing genes and environment for personalized care. Cell 2021, 184, 1530-1544. [CrossRef] [PubMed]

7. Dodangeh, M.; Dodangeh, M. Metabolic regulation and the anti-obesity perspectives of Brown Adipose Tissue (BAT); a Systematic Review. Obes. Med. 2020, 17, 100163. [CrossRef]

8. Bray, G.A. Medical consequences of obesity. J. Clin. Endocrinol. Metab. 2004, 89, 2583-2589. [CrossRef] [PubMed]

9. Virtanen, K.A.; Lidell, M.E.; Orava, J.; Heglind, M.; Westergren, R.; Niemi, T.; Taittonen, M.; Laine, J.; Savisto, N.-J.; Enerbäck, S.; et al. Functional brown adipose tissue in healthy adults. N. Engl. J. Med. 2009, 360, 1518-1525. [CrossRef]

10. Villarroya, F.; Cereijo, R.; Villarroya, J.; Giralt, M. Brown Adipose Tissue as a Secretory Organ. Nat. Rev. Endocrinol. 2017, 13, 26-35. [CrossRef]

11. Cypess, A.M.; Lehman, S.; Williams, G.; Tal, I.; Rodman, D.; Goldfine, A.B.; Kuo, F.C.; Palmer, E.L.; Tseng, Y.-H.; Doria, A.; et al. Identification and importance of brown adipose tissue in adult humans. N. Engl. J. Med. 2009, 360, 1509-1517. [CrossRef]

12. Cannon, B.; Nedergaard, J. Brown Adipose Tissue: Function and physiological significance. Physiol. Rev. 2004, 84, 277-359. [CrossRef] [PubMed]

13. van Marken Lichtenbelt, W.D.; Vanhommerig, J.W.; Smulders, N.M.; Drossaerts, J.M.A.F.L.; Kemerink, G.J.; Bouvy, N.D.; Schrauwen, P.; Teule, G.J.J. Cold-Activated brown adipose tissue in healthy men. N. Engl. J. Med. 2009, 360, 1500-1508. [CrossRef]

14. Okamatsu-Ogura, Y.; Fukano, K.; Tsubota, A.; Nio-Kobayashi, J.; Nakamura, K.; Morimatsu, M.; Sakaue, H.; Saito, M.; Kimura, K. Cell-Cycle arrest in mature adipocytes impairs bat development but not wat browning, and reduces adaptive thermogenesis in mice. Sci. Rep. 2017, 7, 6648. [CrossRef]

15. Smith, R.L.; Soeters, M.R.; Wüst, R.C.I.; Houtkooper, R.H. Metabolic flexibility as an adaptation to energy resources and requirements in health and disease. Endocr. Rev. 2018, 39, 489-517. [CrossRef] [PubMed]

16. Barquissau, V.; Beuzelin, D.; Pisani, D.F.; Beranger, G.E.; Mairal, A.; Montagner, A.; Roussel, B.; Tavernier, G.; Marques, M.-A.; Moro, C.; et al. White-to-Brite conversion in human adipocytes promotes metabolic reprogramming towards fatty acid anabolic and catabolic pathways. Mol. Metab. 2016, 5, 352-365. [CrossRef]

17. Blondin, D.P.; Nielsen, S.; Kuipers, E.N.; Severinsen, M.C.; Jensen, V.H.; Miard, S.; Jespersen, N.Z.; Kooijman, S.; Boon, M.R.; Fortin, M.; et al. Human brown adipocyte thermogenesis is driven by B2-AR stimulation. Cell. Metab. 2020, 32, $287-300$. [CrossRef] [PubMed]

18. Killick, R.; Banks, S.; Liu, P.Y. Implications of sleep restriction and recovery on metabolic outcomes. J. Clin. Endocrinol. Metab. 2012, 97, 3876-3890. [CrossRef] [PubMed]

19. de Goede, P.; Sen, S.; Su, Y.; Foppen, E.; Poirel, V.-J.; Challet, E.; Kalsbeek, A. An ultradian feeding schedule in rats affects metabolic gene expression in liver, brown adipose tissue and skeletal muscle with only mild effects on circadian clocks. Int. J. Mol. Sci. 2018, 19, 3171. [CrossRef] [PubMed] 
20. Um, J.-H.; Pendergast, J.S.; Springer, D.A.; Foretz, M.; Viollet, B.; Brown, A.; Kim, M.K.; Yamazaki, S.; Chung, J.H. AMPK regulates circadian rhythms in a tissue- and isoform-specific manner. PLoS ONE 2011, 6, e18450. [CrossRef]

21. Mulligan, J.D.; Gonzalez, A.A.; Stewart, A.M.; Carey, H.V.; Saupe, K.W. Upregulation of AMPK during cold exposure occurs via distinct mechanisms in brown and white adipose tissue of the mouse. J. Physiol. 2007, 580, 677-684. [CrossRef] [PubMed]

22. Van Dam, A.D.; Kooijman, S.; Schilperoort, M.; Rensen, P.C.N.; Boon, M.R. Regulation of brown fat by AMP-activated protein kinase. Trends Mol. Med. 2015, 21, 571-579. [CrossRef]

23. Wu, L.; Zhang, L.; Li, B.; Jiang, H.; Duan, Y.; Xie, Z.; Shuai, L.; Li, J.; Li, J. AMP-Activated Protein Kinase (AMPK) Regulates Energy Metabolism through Modulating Thermogenesis in Adipose Tissue. Front. Physiol. 2018, 9, 122. [CrossRef]

24. Kooijman, S.; van den Berg, R.; Ramkisoensing, A.; Boon, M.R.; Kuipers, E.N.; Loef, M.; Zonneveld, T.C.M.; Lucassen, E.A.; Sips, H.C.M.; Chatzispyrou, I.A.; et al. Prolonged daily light exposure increases body fat mass through attenuation of brown adipose tissue activity. Proc. Natl. Acad. Sci. USA 2015, 112, 6748-6753. [CrossRef] [PubMed]

25. Ahmad, B.; Serpell, C.J.; Fong, I.L.; Wong, E.H. Molecular mechanisms of adipogenesis: The anti-adipogenic role of AMP-activated protein kinase. Front. Mol. Biosci. 2020, 7. [CrossRef] [PubMed]

26. López, M. Hypothalamic AMPK and energy balance. Eur. J. Clin. Invest. 2018, 48. [CrossRef] [PubMed]

27. Hardie, D.G. AMPK as a direct sensor of long-chain fatty Acyl-CoA esters. Nat. Metab. 2020, 2, 799-800. [CrossRef]

28. Hardie, D.G. Keeping the home fires burning: AMP-Activated Protein Kinase. J. R. Soc. Interface 2018, 15. [CrossRef] [PubMed]

29. Hardie, D.G. AMPK-Sensing energy while talking to other signaling pathways. Cell Metab. 2014, 20, 939-952. [CrossRef]

30. Hardie, D.G.; Schaffer, B.E.; Brunet, A. AMPK: An energy-sensing pathway with multiple inputs and outputs. Trends Cell Biol. 2016, 26, 190-201. [CrossRef]

31. Pinkosky, S.L.; Scott, J.W.; Desjardins, E.M.; Smith, B.K.; Day, E.A.; Ford, R.J.; Langendorf, C.G.; Ling, N.X.Y.; Nero, T.L.; Loh, K.; et al. Long-Chain fatty Acyl-CoA esters regulate metabolism via allosteric control of AMPK B1 Isoforms. Nat. Metab. 2020, 2, 873-881. [CrossRef]

32. Hardie, D.G.; Scott, J.W.; Pan, D.A.; Hudson, E.R. Management of cellular energy by the AMP-Activated protein kinase system. Febs. Lett. 2003, 546, 113-120. [CrossRef]

33. Garcia, D.; Shaw, R.J. AMPK: Mechanisms of cellular energy sensing and restoration of metabolic balance. Mol. Cell. 2017, 66, 789-800. [CrossRef] [PubMed]

34. Hawley, S.A.; Boudeau, J.; Reid, J.L.; Mustard, K.J.; Udd, L.; Mäkelä, T.P.; Alessi, D.R.; Hardie, D.G. Complexes between the LKB1 tumor suppressor, STRAD $\alpha / \beta$ and $\mathrm{MO} 25 \alpha / \beta$ are upstream kinases in the AMP-Activated protein kinase cascade. J. Biol. 2003, 2, 28. [CrossRef] [PubMed]

35. Woods, A.; Johnstone, S.R.; Dickerson, K.; Leiper, F.C.; Fryer, L.G.D.; Neumann, D.; Schlattner, U.; Wallimann, T.; Carlson, M.; Carling, D. LKB1 is the upstream kinase in the AMP-Activated protein kinase cascade. Curr. Biol. 2003, 13, 2004-2008. [CrossRef]

36. Hawley, S.A.; Davison, M.; Woods, A.; Davies, S.P.; Beri, R.K.; Carling, D.; Hardie, D.G. Characterization of the AMP-Activated protein kinase kinase from rat liver and identification of threonine 172 as the major site at which it phosphorylates AMP-Activated protein kinase. J. Biol. Chem. 1996, 271, 27879-27887. [CrossRef]

37. Shaw, R.J.; Kosmatka, M.; Bardeesy, N.; Hurley, R.L.; Witters, L.A.; DePinho, R.A.; Cantley, L.C. The tumor suppressor LKB1 kinase directly activates AMP-Activated kinase and regulates apoptosis in response to energy stress. Proc. Natl. Acad. Sci. USA 2004, 101, 3329-3335. [CrossRef]

38. Hawley, S.A.; Pan, D.A.; Mustard, K.J.; Ross, L.; Bain, J.; Edelman, A.M.; Frenguelli, B.G.; Hardie, D.G. Calmodulin-Dependent protein kinase kinase-beta is an alternative upstream kinase for AMP-Activated protein kinase. Cell. Metab. 2005, 2, 9-19. [CrossRef]

39. Woods, A.; Dickerson, K.; Heath, R.; Hong, S.-P.; Momcilovic, M.; Johnstone, S.R.; Carlson, M.; Carling, D. Ca2+/Calmodulindependent protein kinase kinase-beta acts upstream of AMP-Activated protein kinase in mammalian cells. Cell Metab. 2005, 2, 21-33. [CrossRef] [PubMed]

40. Geerling, J.J.; Boon, M.R.; van der Zon, G.C.; van den Berg, S.A.A.; van den Hoek, A.M.; Lombès, M.; Princen, H.M.G.; Havekes, L.M.; Rensen, P.C.N.; Guigas, B. Metformin lowers plasma triglycerides by promoting VLDL-Triglyceride clearance by brown adipose tissue in mice. Diabetes 2014, 63, 880-891. [CrossRef]

41. Madiraju, A.K.; Erion, D.M.; Rahimi, Y.; Zhang, X.-M.; Braddock, D.; Albright, R.A.; Prigaro, B.J.; Wood, J.L.; Bhanot, S.; MacDonald, M.J.; et al. Metformin suppresses gluconeogenesis by inhibiting mitochondrial glycerophosphate dehydrogenase. Nature 2014, 510, 542-546. [CrossRef] [PubMed]

42. Duca, F.A.; Côté, C.D.; Rasmussen, B.A.; Zadeh-Tahmasebi, M.; Rutter, G.A.; Filippi, B.M.; Lam, T.K.T. Metformin activates duodenal AMPK and a neuronal network to lower glucose production. Nat. Med. 2015, 21, 506-511. [CrossRef] [PubMed]

43. Hardie, D.G. AMPK: A target for drugs and natural products with effects on both diabetes and cancer. Diabetes 2013, 62, 2164-2172. [CrossRef] [PubMed]

44. Wu, L.; Xia, M.; Duan, Y.; Zhang, L.; Jiang, H.; Hu, X.; Yan, H.; Zhang, Y.; Gu, Y.; Shi, H.; et al. Berberine promotes the recruitment and activation of brown adipose tissue in mice and humans. Cell Death Dis. 2019, 10, 468. [CrossRef]

45. Corton, J.M.; Gillespie, J.G.; Hawley, S.A.; Hardie, D.G. 5-Aminoimidazole-4-Carboxamide Ribonucleoside. A specific method for activating AMP-Activated protein kinase in intact cells? Eur. J. Biochem. 1995, 229, 558-565. [CrossRef]

46. Carling, D. AMPK signalling in health and disease. Curr. Opin. Cell. Biol. 2017, 45, 31-37. [CrossRef] [PubMed] 
47. Sanders, M.J.; Ali, Z.S.; Hegarty, B.D.; Heath, R.; Snowden, M.A.; Carling, D. Defining the mechanism of activation of AMPActivated protein kinase by the small molecule A-769662, a member of the Thienopyridone family. J. Biol. Chem. 2007, 282, 32539-32548. [CrossRef]

48. Salt, I.P.; Hardie, D.G. AMP-Activated protein kinase a ubiquitous signalling pathway with key roles in the cardiovascular system. Circ. Res. 2017, 120, 1825-1841. [CrossRef]

49. Hawley, S.A.; Ross, F.A.; Chevtzoff, C.; Green, K.A.; Evans, A.; Fogarty, S.; Towler, M.C.; Brown, L.J.; Ogunbayo, O.A.; Evans, A.M.; et al. Use of cells expressing $\gamma$ subunit variants to identify diverse mechanisms of AMPK activation. Cell Metab. 2010, 11, 554-565. [CrossRef]

50. de Ligt, M.; Timmers, S.; Schrauwen, P. Resveratrol and obesity: Can resveratrol relieve metabolic disturbances? Biochim. Biophys. Acta 2015, 1852, 1137-1144. [CrossRef]

51. Lagouge, M.; Argmann, C.; Gerhart-Hines, Z.; Meziane, H.; Lerin, C.; Daussin, F.; Messadeq, N.; Milne, J.; Lambert, P.; Elliott, P.; et al. Resveratrol improves mitochondrial function and protects against metabolic disease by activating SIRT1 and PGC-1alpha. Cell 2006, 127, 1109-1122. [CrossRef]

52. Madreiter-Sokolowski, C.T.; Sokolowski, A.A.; Graier, W.F. Dosis Facit Sanitatem-Concentration-Dependent effects of Resveratrol on Mitochondria. Nutrients 2017, 9, 1117. [CrossRef]

53. Zheng, J.; Ramirez, V.D. Inhibition of mitochondrial proton F0F1-ATPase/ATP synthase by Polyphenolic Phytochemicals. Br. J. Pharm. 2000, 130, 1115-1123. [CrossRef]

54. Turner, N.; Li, J.-Y.; Gosby, A.; To, S.W.C.; Cheng, Z.; Miyoshi, H.; Taketo, M.M.; Cooney, G.J.; Kraegen, E.W.; James, D.E.; et al. Berberine and its more biologically available derivative, Dihydroberberine, inhibit mitochondrial respiratory complex i: A mechanism for the action of berberine to activate AMP-Activated protein kinase and improve insulin action. Diabetes 2008, 57, 1414-1418. [CrossRef] [PubMed]

55. Jeong, J.H.; Chang, J.S.; Jo, Y.-H. Intracellular glycolysis in brown adipose tissue is essential for optogenetically induced nonshivering thermogenesis in mice. Sci. Rep. 2018, 8. [CrossRef] [PubMed]

56. Held, N.M.; Kuipers, E.N.; van Weeghel, M.; van Klinken, J.B.; Denis, S.W.; Lombès, M.; Wanders, R.J.; Vaz, F.M.; Rensen, P.C.N.; Verhoeven, A.J.; et al. Pyruvate Dehydrogenase complex plays a central role in brown adipocyte energy expenditure and fuel utilization during short-term beta-adrenergic activation. Sci. Rep. 2018, 8. [CrossRef]

57. Anthony, N.M.; Gaidhu, M.P.; Ceddia, R.B. Regulation of visceral and subcutaneous Adipocyte Lipolysis by acute AICAR-induced AMPK activation. Obesity 2009, 17, 1312-1317. [CrossRef] [PubMed]

58. Cokorinos, E.C.; Delmore, J.; Reyes, A.R.; Albuquerque, B.; Kjøbsted, R.; Jørgensen, N.O.; Tran, J.-L.; Jatkar, A.; Cialdea, K.; Esquejo, R.M.; et al. Activation of skeletal muscle AMPK promotes glucose disposal and glucose lowering in non-human primates and mice. Cell Metab. 2017, 25, 1147-1159. [CrossRef]

59. Salatto, C.T.; Miller, R.A.; Cameron, K.O.; Cokorinos, E.; Reyes, A.; Ward, J.; Calabrese, M.F.; Kurumbail, R.G.; Rajamohan, F.; Kalgutkar, A.S.; et al. Selective activation of AMPK B1-Containing isoforms improves kidney function in a rat model of diabetic nephropathy. J. Pharm. Exp. 2017, 361, 303-311. [CrossRef]

60. Myers, R.W.; Guan, H.-P.; Ehrhart, J.; Petrov, A.; Prahalada, S.; Tozzo, E.; Yang, X.; Kurtz, M.M.; Trujillo, M.; Gonzalez Trotter, D.; et al. Systemic Pan-AMPK Activator MK-8722 improves glucose homeostasis but induces cardiac hypertrophy. Science 2017, 357, 507-511. [CrossRef]

61. Feng, D.; Biftu, T.; Romero, F.A.; Kekec, A.; Dropinski, J.; Kassick, A.; Xu, S.; Kurtz, M.M.; Gollapudi, A.; Shao, Q.; et al. Discovery of MK-8722: A systemic, direct pan-activator of AMP-Activated protein kinase. ACS Med. Chem. Lett. 2018, 9, 39-44. [CrossRef]

62. Cameron, K.O.; Kung, D.W.; Kalgutkar, A.S.; Kurumbail, R.G.; Miller, R.; Salatto, C.T.; Ward, J.; Withka, J.M.; Bhattacharya, S.K.; Boehm, M.; et al. Discovery and preclinical characterization of 6-Chloro-5-[4-(1-Hydroxycyclobutyl)Phenyl]-1H-Indole3-Carboxylic Acid (PF-06409577), a direct activator of Adenosine Monophosphate-Activated Protein Kinase (AMPK), for the potential treatment of diabetic nephropathy. J. Med. Chem. 2016, 59, 8068-8081. [CrossRef] [PubMed]

63. Ryder, T.F.; Calabrese, M.F.; Walker, G.S.; Cameron, K.O.; Reyes, A.R.; Borzilleri, K.A.; Delmore, J.; Miller, R.; Kurumbail, R.G.; Ward, J.; et al. Acyl Glucuronide Metabolites of 6-Chloro-5-[4-(1-Hydroxycyclobutyl)Phenyl]-1 H-Indole-3-Carboxylic Acid (PF-06409577) and related Indole-3-Carboxylic acid derivatives are direct activators of Adenosine Monophosphate-Activated Protein Kinase (AMPK). J. Med. Chem. 2018, 61, 7273-7288. [CrossRef] [PubMed]

64. López, M.; Tena-Sempere, M. Estradiol effects on Hypothalamic AMPK and BAT Thermogenesis: A gateway for obesity treatment? Pharmacol. Ther. 2017, 178, 109-122. [CrossRef] [PubMed]

65. DiMicco, J.A.; Zaretsky, D.V. The dorsomedial hypothalamus: A new player in thermoregulation. Am. J. Physiol. -Regul. Integr. Comp. Physiol. 2007, 292, R47-R63. [CrossRef] [PubMed]

66. Contreras, C.; Gonzalez, F.; Fernø, J.; Diéguez, C.; Rahmouni, K.; Nogueiras, R.; López, M. The brain and brown fat. Ann. Med. 2015, 47, 150-168. [CrossRef] [PubMed]

67. López, M.; Nogueiras, R.; Tena-Sempere, M.; Diéguez, C. Hypothalamic AMPK: A canonical regulator of whole-body energy balance. Nat. Rev. Endocrinol. 2016, 12, 421-432. [CrossRef] [PubMed]

68. López, M.; Varela, L.; Vázquez, M.J.; Rodríguez-Cuenca, S.; González, C.R.; Velagapudi, V.R.; Morgan, D.A.; Schoenmakers, E.; Agassandian, K.; Lage, R.; et al. Hypothalamic AMPK and fatty acid metabolism mediate thyroid regulation of energy balance. Nat. Med. 2010, 16, 1001-1008. [CrossRef] 
69. Wang, B.; Cheng, K.K.-Y. Hypothalamic AMPK as a mediator of hormonal regulation of energy balance. Int. J. Mol. Sci. 2018, 19, 3552. [CrossRef]

70. Majdic, G.; Young, M.; Gomez-Sanchez, E.; Anderson, P.; Szczepaniak, L.S.; Dobbins, R.L.; McGarry, J.D.; Parker, K.L. Knockout mice lacking steroidogenic factor 1 are a novel genetic model of hypothalamic obesity. Endocrinology 2002, 143, 607-614. [CrossRef] [PubMed]

71. Martínez-Sánchez, N.; Seoane-Collazo, P.; Contreras, C.; Varela, L.; Villarroya, J.; Rial-Pensado, E.; Buqué, X.; Aurrekoetxea, I.; Delgado, T.C.; Vázquez-Martínez, R.; et al. Hypothalamic AMPK-ER Stress-JNK1 axis mediates the central actions of thyroid hormones on energy balance. Cell Metab. 2017, 26, 212-229. [CrossRef] [PubMed]

72. Seoane-Collazo, P.; Roa, J.; Rial-Pensado, E.; Liñares-Pose, L.; Beiroa, D.; Ruíz-Pino, F.; López-González, T.; Morgan, D.A.; Pardavila, J.Á.; Sánchez-Tapia, M.J.; et al. SF1-Specific AMPK $\alpha 1$ deletion protects against diet-induced obesity. Diabetes 2018, 67, 2213-2226. [CrossRef] [PubMed]

73. Tong, Q.; Ye, C.; McCrimmon, R.J.; Dhillon, H.; Choi, B.; Kramer, M.D.; Yu, J.; Yang, Z.; Christiansen, L.M.; Lee, C.E.; et al. Synaptic glutamate release by ventromedial hypothalamic neurons is part of the neurocircuitry that prevents hypoglycemia. Cell Metab. 2007, 5, 383-393. [CrossRef]

74. Xu, Y.; Nedungadi, T.P.; Zhu, L.; Sobhani, N.; Irani, B.G.; Davis, K.E.; Zhang, X.; Zou, F.; Gent, L.M.; Hahner, L.D.; et al. Distinct Hypothalamic neurons mediate estrogenic effects on energy homeostasis and reproduction. Cell Metab. 2011, 14, 453-465. [CrossRef] [PubMed]

75. Alvarez-Crespo, M.; Csikasz, R.I.; Martínez-Sánchez, N.; Diéguez, C.; Cannon, B.; Nedergaard, J.; López, M. Essential role of UCP1 modulating the central effects of thyroid hormones on energy balance. Mol. Metab. 2016, 5, 271-282. [CrossRef]

76. Martínez-Sánchez, N.; Moreno-Navarrete, J.M.; Contreras, C.; Rial-Pensado, E.; Fernø, J.; Nogueiras, R.; Diéguez, C.; FernándezReal, J.-M.; López, M. Thyroid hormones induce browning of white fat. J. Endocrinol. 2016, 232, 351-362. [CrossRef] [PubMed]

77. Mauvais-Jarvis, F.; Clegg, D.J.; Hevener, A.L. The role of estrogens in control of energy balance and glucose homeostasis. Endocr. Rev. 2013, 34, 309-338. [CrossRef] [PubMed]

78. Martínez de Morentin, P.B.; González-García, I.; Martins, L.; Lage, R.; Fernández-Mallo, D.; Martínez-Sánchez, N.; Ruíz-Pino, F.; Liu, J.; Morgan, D.A.; Pinilla, L.; et al. Estradiol regulates brown adipose tissue thermogenesis via hypothalamic AMPK. Cell Metab. 2014, 20, 41-53. [CrossRef] [PubMed]

79. González-García, I.; Contreras, C.; Estévez-Salguero, Á.; Ruíz-Pino, F.; Colsh, B.; Pensado, I.; Liñares-Pose, L.; Rial-Pensado, E.; de Morentin, P.B.M.; Fernø, J.; et al. Estradiol regulates energy balance by ameliorating hypothalamic ceramide-induced ER stress. Cell Rep. 2018, 25, 413-423. [CrossRef]

80. Martínez de Morentin, P.B.; Whittle, A.J.; Fernø, J.; Nogueiras, R.; Diéguez, C.; Vidal-Puig, A.; López, M. nicotine induces negative energy balance through hypothalamic AMP-Activated protein kinase. Diabetes 2012, 61, 807-817. [CrossRef]

81. Seoane-Collazo, P.; de Morentin, P.B.M.; Fernø, J.; Diéguez, C.; Nogueiras, R.; López, M. nicotine improves obesity and hepatic steatosis and ER stress in diet-induced obese male rats. Endocrinology 2014, 155, 1679-1689. [CrossRef] [PubMed]

82. Arai, K.; Kim, K.; Kaneko, K.; Iketani, M.; Otagiri, A.; Yamauchi, N.; Shibasaki, T. Nicotine infusion alters leptin and uncoupling protein 1 MRNA expression in adipose tissues of rats. Am. J. Physiol. Endocrinol. Metab. 2001, 280, E867-E876. [CrossRef] [PubMed]

83. Mano-Otagiri, A.; Iwasaki-Sekino, A.; Ohata, H.; Arai, K.; Shibasaki, T. Nicotine suppresses energy storage through activation of sympathetic outflow to brown adipose tissue via corticotropin-releasing factor type 1 receptor. Neurosci. Lett. 2009, 455, 26-29. [CrossRef]

84. Nishii, N.; Arai, M.; Yanai, N.; Togari, A.; Nakabayashi, T. Effect of Bone Morphogenetic Protein-2 (BMP-2) or Troglitazone, as an inducer of osteogenic cells or adipocytes, on differentiation of a bone marrow mesenchymal progenitor cell line established from Temperature-Sensitive (Ts) Simian Virus (SV) 40 T-Antigen Gene Transgenic Mice. Biol. Pharm. Bull. 2009, 32, 10-17. [CrossRef]

85. Sottile, V.; Seuwen, K. Bone morphogenetic protein-2 stimulates adipogenic differentiation of mesenchymal precursor cells in synergy with BRL 49653 (Rosiglitazone). FEBS Lett. 2000, 475, 201-204. [CrossRef]

86. Tang, Q.-Q.; Otto, T.C.; Lane, M.D. Commitment of C3H10T1/2 Pluripotent stem cells to the adipocyte lineage. Proc. Natl. Acad Sci. USA 2004, 101, 9607-9611. [CrossRef]

87. Schulz, T.J.; Huang, T.L.; Tran, T.T.; Zhang, H.; Townsend, K.L.; Shadrach, J.L.; Cerletti, M.; McDougall, L.E.; Giorgadze, N.; Tchkonia, T.; et al. Identification of inducible brown adipocyte progenitors residing in skeletal muscle and white fat. Proc. Natl. Acad. Sci. USA 2011, 108, 143-148. [CrossRef]

88. Tseng, Y.-H.; Kokkotou, E.; Schulz, T.J.; Huang, T.L.; Winnay, J.N.; Taniguchi, C.M.; Tran, T.T.; Suzuki, R.; Espinoza, D.O.; Yamamoto, Y.; et al. New role of bone morphogenetic protein 7 in brown adipogenesis and energy expenditure. Nature 2008, 454, 1000-1004. [CrossRef] [PubMed]

89. Whittle, A.J.; Carobbio, S.; Martins, L.; Slawik, M.; Hondares, E.; Vázquez, M.J.; Morgan, D.; Csikasz, R.I.; Gallego, R.; RodriguezCuenca, S.; et al. BMP8B increases brown adipose tissue thermogenesis through both central and peripheral actions. Cell 2012, 149, 871-885. [CrossRef]

90. Martins, L.; Seoane-Collazo, P.; Contreras, C.; González-García, I.; Martínez-Sánchez, N.; González, F.; Zalvide, J.; Gallego, R.; Diéguez, C.; Nogueiras, R.; et al. A functional link between AMPK and Orexin mediates the effect of BMP8B on energy balance. Cell Rep. 2016, 16, 2231-2242. [CrossRef] [PubMed] 
91. Janssen, L.G.M.; Nahon, K.J.; Bracké, K.F.M.; van den Broek, D.; Smit, R.; Sardjoe Mishre, A.S.D.; Koorneef, L.L.; Martinez-Tellez, B.; Burakiewicz, J.; Kan, H.E.; et al. Twelve weeks of exenatide treatment increases [18F]Fluorodeoxyglucose uptake by brown adipose tissue without affecting oxidative resting energy expenditure in nondiabetic males. Metabolism 2020, $106,154167$. [CrossRef] [PubMed]

92. Lee, S.J.; Sanchez-Watts, G.; Krieger, J.-P.; Pignalosa, A.; Norell, P.N.; Cortella, A.; Pettersen, K.G.; Vrdoljak, D.; Hayes, M.R.; Kanoski, S.E.; et al. Loss of dorsomedial hypothalamic GLP-1 signaling reduces BAT Thermogenesis and increases adiposity. Mol. Metab. 2018, 11, 33-46. [CrossRef] [PubMed]

93. Kooijman, S.; Wang, Y.; Parlevliet, E.T.; Boon, M.R.; Edelschaap, D.; Snaterse, G.; Pijl, H.; Romijn, J.A.; Rensen, P.C.N. Central GLP-1 receptor signalling accelerates plasma clearance of triacylglycerol and glucose by activating brown adipose tissue in mice. Diabetologia 2015, 58, 2637-2646. [CrossRef] [PubMed]

94. Lockie, S.H.; Heppner, K.M.; Chaudhary, N.; Chabenne, J.R.; Morgan, D.A.; Veyrat-Durebex, C.; Ananthakrishnan, G.; RohnerJeanrenaud, F.; Drucker, D.J.; DiMarchi, R.; et al. Direct control of brown adipose tissue thermogenesis by central nervous system glucagon-like peptide-1 receptor signaling. Diabetes 2012, 61, 2753-2762. [CrossRef] [PubMed]

95. Beiroa, D.; Imbernon, M.; Gallego, R.; Senra, A.; Herranz, D.; Villarroya, F.; Serrano, M.; Fernø, J.; Salvador, J.; Escalada, J.; et al. GLP-1 agonism stimulates brown adipose tissue thermogenesis and browning through hypothalamic AMPK. Diabetes 2014, 63, 3346-3358. [CrossRef] [PubMed]

96. Kim, M.-S.; Park, J.-Y.; Namkoong, C.; Jang, P.-G.; Ryu, J.-W.; Song, H.-S.; Yun, J.-Y.; Namgoong, I.-S.; Ha, J.; Park, I.-S.; et al. Anti-Obesity effects of $\alpha$-lipoic acid mediated by suppression of hypothalamic AMP-Activated protein kinase. Nat. Med. 2004, 10, 727-733. [CrossRef] [PubMed]

97. Li, N.; Yan, W.; Hu, X.; Huang, Y.; Wang, F.; Zhang, W.; Wang, Q.; Wang, X.; Sun, K. Effects of Oral $\alpha$-Lipoic acid administration on body weight in overweight or obese subjects: A crossover randomized, double-blind, placebo-controlled trial. Clin. Endocrinol. 2017, 86, 680-687. [CrossRef] [PubMed]

98. Koh, E.H.; Lee, W.J.; Lee, S.A.; Kim, W.H.; Cho, E.H.; Jeong, E.; Kim, D.W.; Kim, M.S.; Park, J.Y.; Park, K.G.; et al. Efects of alpha-lipoic acid on body weight in obese subjects. Am. J. Med. 2011, 124, e1-e85. [CrossRef] [PubMed]

99. Zhang, Z.; Zhang, H.; Li, B.; Meng, X.; Wang, J.; Zhang, Y.; Yao, S.; Ma, Q.; Jin, L.; Yang, J.; et al. Berberine activates thermogenesis in white and brown adipose tissue. Nat. Commun. 2014, 5, 5493. [CrossRef] [PubMed]

100. Mottillo, E.P.; Desjardins, E.M.; Crane, J.D.; Smith, B.K.; Green, A.E.; Ducommun, S.; Henriksen, T.I.; Rebalka, I.A.; Razi, A.; Sakamoto, K.; et al. Lack of adipocyte AMPK exacerbates insulin resistance and hepatic steatosis through brown and beige adipose tissue function. Cell Metab. 2016, 24, 118-129. [CrossRef]

101. Zhao, J.; Yang, Q.; Zhang, L.; Liang, X.; Sun, X.; Wang, B.; Chen, Y.; Zhu, M.; Du, M. AMPK $\alpha 1$ deficiency suppresses brown adipogenesis in favor of fibrogenesis during brown adipose tissue development. Biochem. Biophys. Res. Commun. 2017, 491, 508-514. [CrossRef] [PubMed]

102. Vila-Bedmar, R.; Lorenzo, M.; Fernández-Veledo, S. Adenosine 5'-Monophosphate-Activated protein kinase-mammalian target of rapamycin cross talk regulates brown adipocyte differentiation. Endocrinology 2010, 151, 980-992. [CrossRef] [PubMed]

103. Shaw, R.J. LKB1 and AMP-Activated protein kinase control of MTOR signalling and growth. Acta Physiol. 2009, 196, 65-80. [CrossRef] [PubMed]

104. Inoki, K.; Zhu, T.; Guan, K.-L. TSC2 mediates cellular energy response to control cell growth and survival. Cell 2003, 115, 577-590. [CrossRef]

105. Agarwal, S.; Bell, C.M.; Rothbart, S.B.; Moran, R.G. AMP-Activated Protein Kinase (AMPK) control of MTORC1 Is P53- and TSC2-Independent in pemetrexed-treated carcinoma cells. J. Biol. Chem. 2015, 290, 27473-27486. [CrossRef]

106. Desjardins, E.M.; Steinberg, G.R. Emerging Role of AMPK in Brown and Beige Adipose Tissue (BAT): Implications for obesity, insulin resistance, and type 2 diabetes. Curr. Diab. Rep. 2018, 18, 80. [CrossRef]

107. Olsen, J.M.; Sato, M.; Dallner, O.S.; Sandström, A.L.; Pisani, D.F.; Chambard, J.-C.; Amri, E.-Z.; Hutchinson, D.S.; Bengtsson, T. Glucose uptake in brown fat cells is dependent on MTOR complex 2-promoted GLUT1 translocation. J. Cell. Biol. 2014, 207, 365-374. [CrossRef]

108. Olsen, J.M.; Csikasz, R.I.; Dehvari, N.; Lu, L.; Sandström, A.; Öberg, A.I.; Nedergaard, J.; Stone-Elander, S.; Bengtsson, T. B3-adrenergically induced glucose uptake in brown adipose tissue is independent of UCP1 presence or activity: Mediation through the MTOR pathway. Mol. Metab. 2017, 6, 611-619. [CrossRef]

109. Seale, P.; Bjork, B.; Yang, W.; Kajimura, S.; Chin, S.; Kuang, S.; Scimè, A.; Devarakonda, S.; Conroe, H.M.; Erdjument-Bromage, H.; et al. PRDM16 controls a brown fat/skeletal muscle switch. Nature 2008, 454, 961-967. [CrossRef]

110. Yang, Q.; Liang, X.; Sun, X.; Zhang, L.; Fu, X.; Rogers, C.J.; Berim, A.; Zhang, S.; Wang, S.; Wang, B.; et al. AMPK/ $\alpha$-Ketoglutarate axis dynamically mediates DNA demethylation in the prdm16 promoter and brown adipogenesis. Cell Metab. 2016, 24, 542-554. [CrossRef]

111. Cao, Y.; Liu, X.; Zhao, J.; Du, M. AMPK $\alpha 1$ regulates Idh2 transcription through H2B O-GlcNAcylation during brown adipogenesis. Acta Biochim. Biophys. Sin. 2021, 53, 112-118. [CrossRef] [PubMed]

112. Herzig, S.; Shaw, R.J. AMPK: Guardian of metabolism and mitochondrial homeostasis. Nat. Rev. Mol. Cell. Biol. 2018, 19, 121-135. [CrossRef] [PubMed]

113. Zhang, J.; Wang, Y.; Liu, X.; Dagda, R.K.; Zhang, Y. How AMPK and PKA interplay to regulate mitochondrial function and survival in models of ischemia and diabetes. Oxid. Med. Cell. Longev. 2017, 2017, 4353510. [CrossRef] 
114. Foretz, M.; Guigas, B.; Bertrand, L.; Pollak, M.; Viollet, B. Metformin: From mechanisms of action to therapies. Cell. Metab. 2014, 20, 953-966. [CrossRef]

115. Kjøbsted, R.; Munk-Hansen, N.; Birk, J.B.; Foretz, M.; Viollet, B.; Björnholm, M.; Zierath, J.R.; Treebak, J.T.; Wojtaszewski, J.F.P. Enhanced muscle insulin sensitivity after contraction/exercise is mediated by AMPK. Diabetes 2017, 66, 598-612. [CrossRef]

116. Wikstrom, J.D.; Mahdaviani, K.; Liesa, M.; Sereda, S.B.; Si, Y.; Las, G.; Twig, G.; Petrovic, N.; Zingaretti, C.; Graham, A.; et al. Hormone-Induced mitochondrial fission is utilized by brown adipocytes as an amplification pathway for energy expenditure. Embo. J. 2014, 33, 418-436. [CrossRef] [PubMed]

117. Toyama, E.Q.; Herzig, S.; Courchet, J.; Lewis, T.L.; Losón, O.C.; Hellberg, K.; Young, N.P.; Chen, H.; Polleux, F.; Chan, D.C.; et al. Metabolism. AMP-Activated protein kinase mediates mitochondrial fission in response to energy stress. Science 2016, 351, 275-281. [CrossRef] [PubMed]

118. Perdikari, A.; Kulenkampff, E.; Rudigier, C.; Neubauer, H.; Luippold, G.; Redemann, N.; Wolfrum, C. A high-throughput, image-based screen to identify kinases involved in brown adipocyte development. Sci. Signal. 2017, 10. [CrossRef]

119. Perdikari, A.; Leparc, G.G.; Balaz, M.; Pires, N.D.; Lidell, M.E.; Sun, W.; Fernandez-Albert, F.; Müller, S.; Akchiche, N.; Dong, H.; et al. BATLAS: Deconvoluting brown adipose tissue. Cell Rep. 2018, 25, 784-797.e4. [CrossRef] [PubMed]

120. Finlin, B.S.; Memetimin, H.; Zhu, B.; Confides, A.L.; Vekaria, H.J.; El Khouli, R.H.; Johnson, Z.R.; Westgate, P.M.; Chen, J.; Morris, A.J.; et al. The B3-Adrenergic receptor agonist mirabegron improves glucose homeostasis in obese humans. J. Clin. Investig. 2020, 130, 2319-2331. [CrossRef]

121. O’Mara, A.E.; Johnson, J.W.; Linderman, J.D.; Brychta, R.J.; McGehee, S.; Fletcher, L.A.; Fink, Y.A.; Kapuria, D.; Cassimatis, T.M.; Kelsey, N.; et al. Chronic mirabegron treatment increases human brown fat, HDL cholesterol, and insulin sensitivity. J. Clin. Investig. 2020, 130, 2209-2219. [CrossRef] [PubMed]

122. Bernardo, B.; Lu, M.; Bandyopadhyay, G.; Li, P.; Zhou, Y.; Huang, J.; Levin, N.; Tomas, E.M.; Calle, R.A.; Erion, D.M.; et al. FGF21 does not require interscapular brown adipose tissue and improves liver metabolic profile in animal models of obesity and insulin-resistance. Sci. Rep. 2015, 5, 11382. [CrossRef] [PubMed]

123. Chau, M.D.L.; Gao, J.; Yang, Q.; Wu, Z.; Gromada, J. Fibroblast growth factor 21 regulates energy metabolism by activating the AMPK-SIRT1-PGC-1alpha pathway. Proc. Natl. Acad. Sci. USA 2010, 107, 12553-12558. [CrossRef] [PubMed]

124. Mottillo, E.P.; Desjardins, E.M.; Fritzen, A.M.; Zou, V.Z.; Crane, J.D.; Yabut, J.M.; Kiens, B.; Erion, D.M.; Lanba, A.; Granneman, J.G.; et al. FGF21 does not require adipocyte AMP-Activated Protein Kinase (AMPK) or the Phosphorylation of Acetyl-CoA Carboxylase (ACC) to mediate improvements in whole-body glucose homeostasis. Mol. Metab. 2017, 6, 471-481. [CrossRef]

125. Bertholet, A.M.; Kazak, L.; Chouchani, E.T.; Bogaczyńska, M.G.; Paranjpe, I.; Wainwright, G.L.; Bétourné, A.; Kajimura, S.; Spiegelman, B.M.; Kirichok, Y. Mitochondrial patch clamp of beige adipocytes reveals UCP1-Positive and UCP1-Negative cells both exhibiting futile creatine cycling. Cell Metab. 2017, 25, 811-822. [CrossRef] [PubMed]

126. Ikeda, K.; Kang, Q.; Yoneshiro, T.; Camporez, J.P.; Maki, H.; Homma, M.; Shinoda, K.; Chen, Y.; Lu, X.; Maretich, P.; et al. UCP1-independent signaling involving SERCA2b-Mediated calcium cycling regulates beige fat thermogenesis and systemic glucose homeostasis. Nat. Med. 2017, 23, 1454-1465. [CrossRef] [PubMed]

127. Kazak, L.; Chouchani, E.T.; Jedrychowski, M.P.; Erickson, B.K.; Shinoda, K.; Cohen, P.; Vetrivelan, R.; Lu, G.Z.; Laznik-Bogoslavski, D.; Hasenfuss, S.C.; et al. A creatine-driven substrate cycle enhances energy expenditure and thermogenesis in beige Fat. Cell 2015, 163, 643-655. [CrossRef]

128. Hanssen, M.J.W.; Hoeks, J.; Brans, B.; van der Lans, A.A.J.J.; Schaart, G.; van den Driessche, J.J.; Jörgensen, J.A.; Boekschoten, M.V.; Hesselink, M.K.C.; Havekes, B.; et al. Short-term cold acclimation improves insulin sensitivity in patients with type 2 diabetes mellitus. Nat. Med. 2015, 21, 863-865. [CrossRef]

129. Remie, C.M.E.; Moonen, M.P.B.; Roumans, K.H.M.; Nascimento, E.B.M.; Gemmink, A.; Havekes, B.; Schaart, G.; Kornips, E.; Joris, P.J.; Schrauwen-Hinderling, V.B.; et al. Metabolic responses to mild cold acclimation in type 2 diabetes patients. Nat. Commun. 2021, 12, 1516. [CrossRef]

130. Fernández-Verdejo, R.; Marlatt, K.L.; Ravussin, E.; Galgani, J.E. Contribution of brown adipose tissue to human energy metabolism. Mol. Asp. Med. 2019, 68, 82-89. [CrossRef]

131. Kong, X.; Yao, T.; Zhou, P.; Kazak, L.; Tenen, D.; Lyubetskaya, A.; Dawes, B.A.; Tsai, L.; Kahn, B.B.; Spiegelman, B.M.; et al. Brown adipose tissue controls skeletal muscle function via the secretion of myostatin. Cell Metab. 2018, 28, 631-643. [CrossRef] [PubMed]

132. Wang, G.-X.; Zhao, X.-Y.; Meng, Z.-X.; Kern, M.; Dietrich, A.; Chen, Z.; Cozacov, Z.; Zhou, D.; Okunade, A.L.; Su, X.; et al. The brown fat-enriched secreted factor nrg4 preserves metabolic homeostasis through attenuation of hepatic lipogenesis. Nat. Med. 2014, 20, 1436-1443. [CrossRef] [PubMed] 